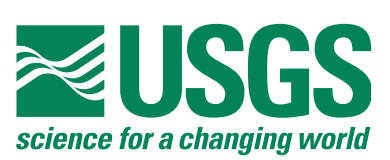

\title{
Use of Short-Term (5-Minute) and Long-Term (18-Hour) Leaching Tests to Characterize, Fingerprint, and Rank Mine-Waste Material from Historical Mines in the Deer Creek, Snake River, and Clear Creek Watersheds in and around the Montezuma Mining District, Colorado
}

By Philip L. Hageman

U.S. Geological Survey Scientific Investigations Report 2004-5104 


\title{
U.S. Department of the Interior
}

\author{
Gale A. Norton, Secretary
}

\section{U.S. Geological Survey}

Charles G. Groat, Director

Posted online July 2004

For more information about the USGS and its products:

Telephone: 1-888-ASK-USGS

World Wide Web: http://www.usgs.gov/

This publication is only available online at:

http://pubs.usgs.gov/sir/2004/5104/ 


\section{Contents}

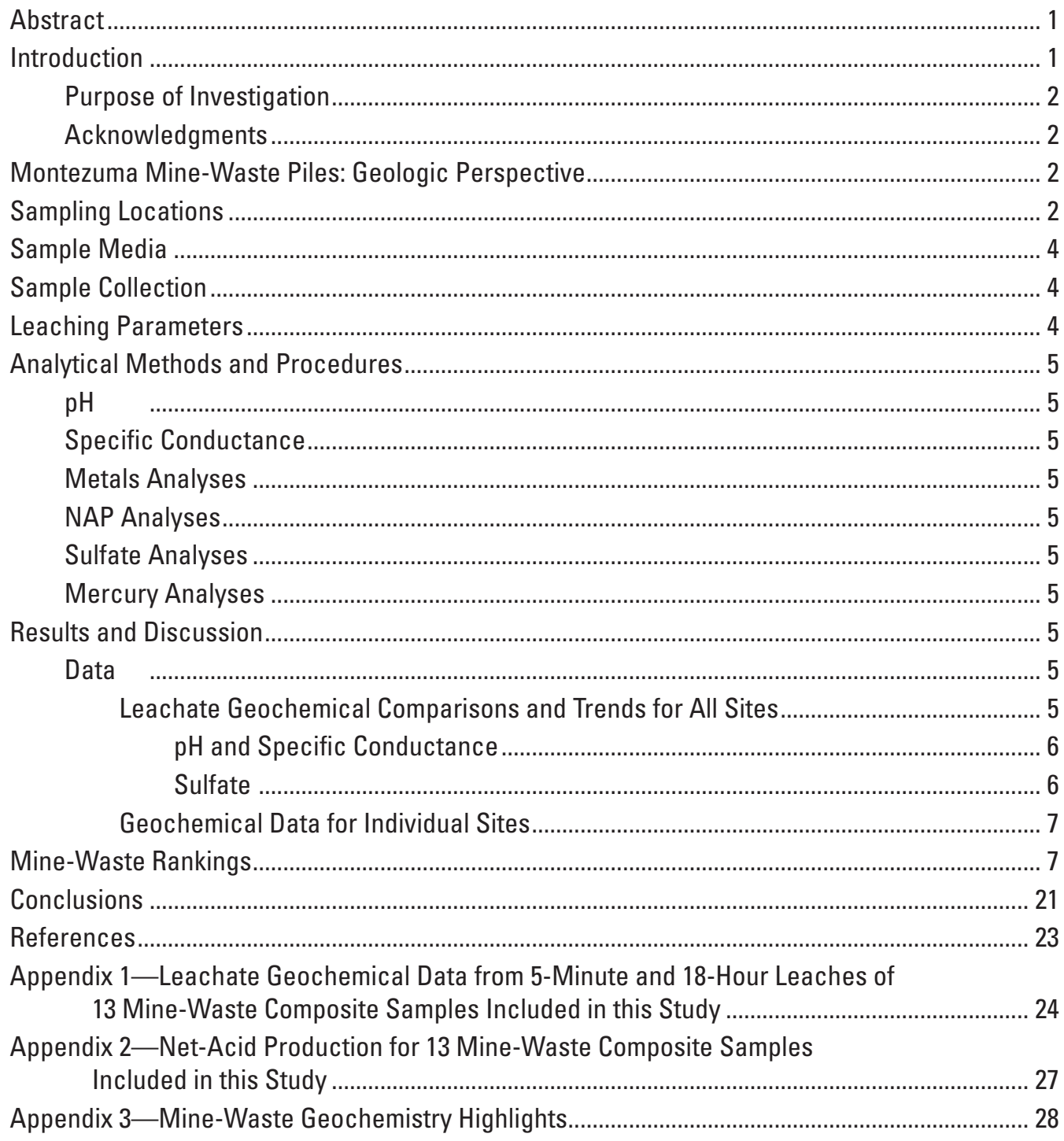

\section{Figures}

1. Location map for 13 mine dumps sampled for this study.................................................. 3

2. Comparison of leachate $\mathrm{pH}$ and specific conductance data for

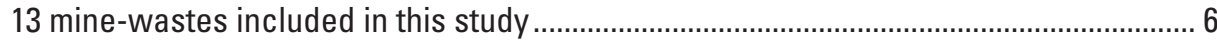

3. Comparison of leachate sulfate data for 13 mine-wastes included in this study............. 7 
4.-16. Mine-waste leachate geochemistry trends for selected major elements, selected trace metals, $\mathrm{pH}$, and specific conductance for:
4. Arabella mine 8

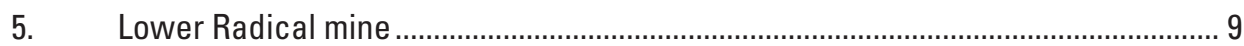

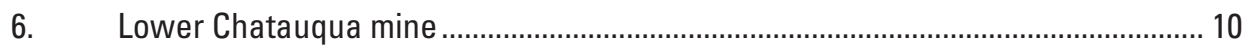

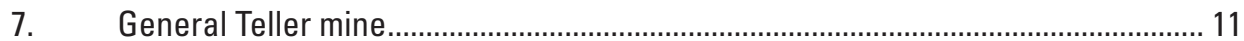

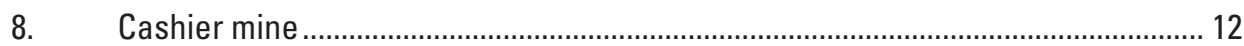

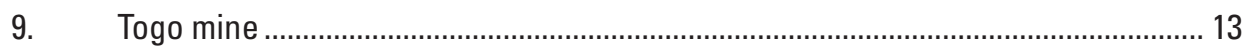

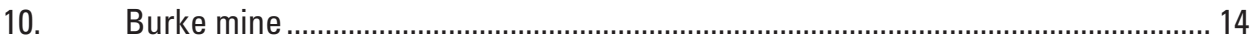

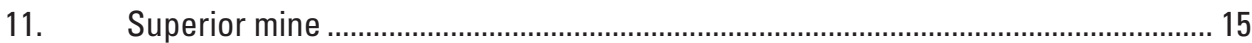

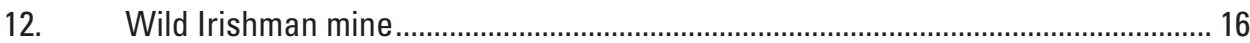

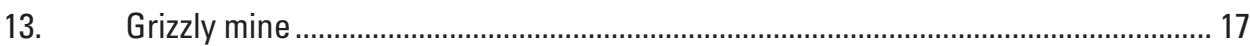

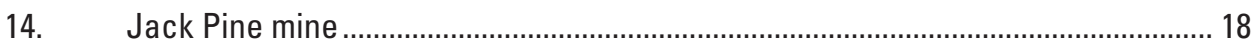

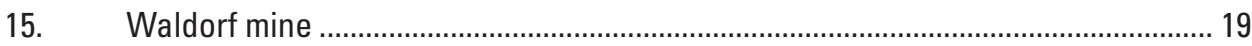

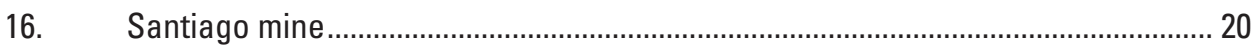

\section{Tables}

1. Mine-wastes sampled, their location, and host-rock formation ....................................... 4

2. Mine-waste rankings for potential effects of runoff due to an event such as a thunderstorm for 13 mine-wastes sampled .................................................... 21

3. Mine-waste rankings for potential effects of runoff due to an extended leaching event (18-hour leach test) for 13 mine-wastes sampled .............. 22

4. Mine-waste rankings for net-acid production ................................................................ 22

A1. Leachate geochemical data from 5-minute and 18-hour leaches of 13 mine-waste composites included in this study ......................................................... 24

A2. Net-acid production for 13 mine-waste composite samples included in this study....... 27 


\title{
Use of Short-Term (5-Minute) and Long-Term (18-Hour) Leaching Tests to Characterize, Fingerprint, and Rank Mine-Waste Material from Historical Mines in the Deer Creek, Snake River, and Clear Creek Watersheds in and around the Montezuma Mining District, Colorado
}

\author{
By Philip L. Hageman
}

\section{Abstract}

Precipitation-induced runoff from historical mine-waste located adjacent to the headwaters of the Snake River, Deer Creek, Saints John Creek, Grizzly Gulch, Stevens Gulch, and Leavenworth Creek contributes to the degradation of water quality in these streams. Because historical mine-waste piles have had long-term exposure to the atmosphere, it is surmised that runoff from these piles, induced by meteorological events such as cloudbursts and snowmelt, may cause mobility of acid and metals into a watershed due to dissolution of soluble minerals. For this study, 13 mine-waste composite samples from various mine-wastes in these drainage basins were leached using both a short-term and a long-term leach test. Analytical results from this combination of leach tests are tools that allow the investigator to quantify (fingerprint) which geochemical components could be expected in runoff from these piles if they were leached by a cloudburst (5-minute leach test), as well as what the "worst-case" geochemical profile would look like if the material were subject to extended leaching and breakdown of the mine-waste material (18-hour leach test). Also, this combination of leach tests allows the geoscientist the ability to see geochemical changes in the mine-waste leachate over time. That is, does the leachate become more or less acidic over time; does the specific conductance increase or decrease; and are there changes in the concentrations of major or trace elements? Further, use of a ranking scheme described herein will aid in prediction of which historical mine-waste piles have the greatest potential for impact on a watershed should runoff occur.

Because of long-term weathering of these historical mine-waste piles, geochemical profiles, leachate time-trends, and relative ranking of the mine-wastes produced from analysis of the leachates are indicative of how the mine-waste piles can be expected to act in the environment and may help to identify the "bad actors" - this may aid in understanding the reasons for water-quality differences between the drainages.

\section{Introduction}

Over time, extensive effort has been made in and around the Montezuma mining district to fully understand the relationship of geology, hydrology, geochemistry, and mineralogy to the environmental impacts observed in watersheds in these areas. Historical mine-wastes are known to be primary point sources for stream-water degradation, and it has been demonstrated that the water quality of the Snake River watershed is impacted by upstream geochemical processes in its headwaters (Munroe, 2000). However, in this study area, distinct streamwater characteristics are seen in adjacent drainage basins that are close to each other spatially but have very different streamwater chemistry and water quality. Examples of these differences in stream-water chemistry for several of the tributaries of the Snake River in the Montezuma mining district are detailed in Fey and others (2002). Although some of the differences in stream-water quality are due to the geologic complexities of these basins, input from mine-adit drainage and runoff from mine-waste piles play a significant ongoing role in streamwater chemistry and quality. These impacts vary depending on the geologic characteristics of the mine-waste material being leached, as is explained in Plumlee and others (1995).

To further aid in the understanding of point-source inputs from various historical mine-wastes in these basins, this study provides leachate geochemical data, or geochemical "fingerprints," of historical mine-waste samples collected from 13 historical mine-wastes in a few of these tributary watersheds. Geochemical data were compared to see if significant geochemical differences in leachate chemistry exist in the mine-waste material from the side-by-side drainages. Comparison of leachate geochemical profiles from mines in these drainage basins helps to explain the reasons for water-quality differences that exist in the streams. Data from this study were also used to profile the probable runoff characteristics of the mine-waste piles (how acidic the runoff would be and what metals could be expected to be mobilized). Geochemical profiling and understanding 
Leaching Tests to Characterize Mine-Waste Material from Historical Mines, Montezuma Mining District, Colo.

probable runoff characteristics is important because flushing of well-weathered mine-waste material by rain or snow can have significant impact as a point source of water-quality degradation due to the migration of acid, metals, and fluvial tailings into the watershed. In addition, this paper provides a way to rank the sites according to their geochemical profile. This ranking scheme can be used to predict which mine-wastes have the potential for greatest impact on stream-water quality.

\section{Purpose of Investigation}

The purpose of this investigation is threefold: First, this report provides other investigators two sets of leachate geochemical data (5-minute leach test and 18-hour leach test) for solid mine-waste composite samples collected from 13 different historical mine-waste sites in the Montezuma mining district and surrounding basins. Leachate data can be used to produce unique geochemical fingerprints for these sites. Further, these data will allow investigators to visualize how runoff from specific piles may impact water resources in these basins. The second purpose of this study was to use leachate geochemical data from this investigation for a comparative study as part of a larger effort to see whether differences can be seen in the geochemical characteristics and time trends of the minewaste leachates from the various basins. Specifically, observations and data were compiled and compared to see if changes in leachate $\mathrm{pH}$, specific conductance, and metal concentrations change over time from the 5-minute leach to the 18-hour leach in order to see whether these trends reveal potential reasons for water-quality differences in streams draining these basins. Net-acid production (NAP) (Lapakko and Lawrence, 1993) was performed on a split of the solid portion of all 13 minewaste samples in order to determine if a correlation can be made between NAP and other geochemical data produced by leaching. Thirdly, after compiling and analyzing the leachate geochemical data from all the sites, this investigation presents a ranking scheme for use in predicting which historical minewaste piles have the greatest potential for negative impact as a point source of acid and metals into a watershed.

\section{Acknowledgments}

I thank Dana Bove for insight and interpretation of the geology for this study and Greg Lee for help with GIS applications.

\section{Montezuma Mine-Waste Piles: Geologic Perspective}

The mine-wastes included in this study represent workings from mesothermal, fissure-filling lead-zinc-silver vein deposits (Lovering, 1938). Galena, sphalerite, pyrite, and quartz are present in most of the veins in the Montezuma mining district and surrounding area and are much more abundant than other vein-related minerals. Copper sulfides are the most abundant of the minor constituents of these ores and were found in most of the vein deposits. Silver, when present in these veins, was generally associated with chalcopyrite and tetrahedrite-tennantite (Lovering, 1935); however, most of the silver in the ores formed as discreet minerals, typically as silver sulfantimonides or sulfarsenides. Quartz is the dominant gangue mineral associated with the Montezuma vein deposits. Ankerite and barite are also common. Ankerite, when present, is reported to contain variable amounts of manganese, iron, and magnesium and weathers black due to high manganese content (Lovering, 1938). Although ankerite is reported in relative abundance in a number of the Montezuma mines (including the Lower Chautauqua, Wild Irishman, and Santiago), when present in mine-waste material, its abundance was probably on the order of 1 percent or less (D. Bove, written commun., 2003). Overall, vein deposits of the Montezuma and surrounding areas are typical of polymetallic vein deposits hosted in noncarbonate rocks, as summarized by Plumlee and others (1995) in a compendium on the geoenvironmental signatures of ore deposits (du Bray, 1995).

Mines west of the upper Snake River drainage basini.e., Deer Creek and Sts. John drainage basins-are hosted in hornblende gneiss or amphibolites (Lovering, 1938). Rocks west of the upper Snake River basin are generally unaltered and lacking in pervasive pyritization except locally around vein deposits (D. Bove, written commun., 2003). In contrast, rocks in the eastern part of the upper Snake River basin are dominantly biotite-quartz-sillimanite schist and gneisses that have been strongly affected by hydrothermal alteration related to Tertiary-age intrusions (Neubert and others, 2004). The most intense alteration and pyritization is focused in the Webster Pass and Handcart Gulch areas.

Clinochlore is present in many of the metamorphic rocks in the Montezuma area and also formed as a replacement of biotite and other iron-magnesium silicates during hydrothermal alteration. Calcite is rarely observed in lithologies of this area, but has been observed along faults and fractures in the hornblende gneisses and amphibolites (D. Bove, written commun., 2003). Although rare, it is also reported in late supergene veinlets that cut vein ores not far from the ground surface, and in late-stage hypogene veinlets and vugs (Lovering, 1938).

\section{Sampling Locations}

In the summers of 2001 and 2002, 13 mine-waste composite samples were collected from a variety of historical mine-wastes located in and around the Montezuma mining district in Colorado. Many of these mine-wastes are identified in Wilson and LaRock (1992) and Munroe (2000). Locations of mine-wastes sampled for this study are identified 


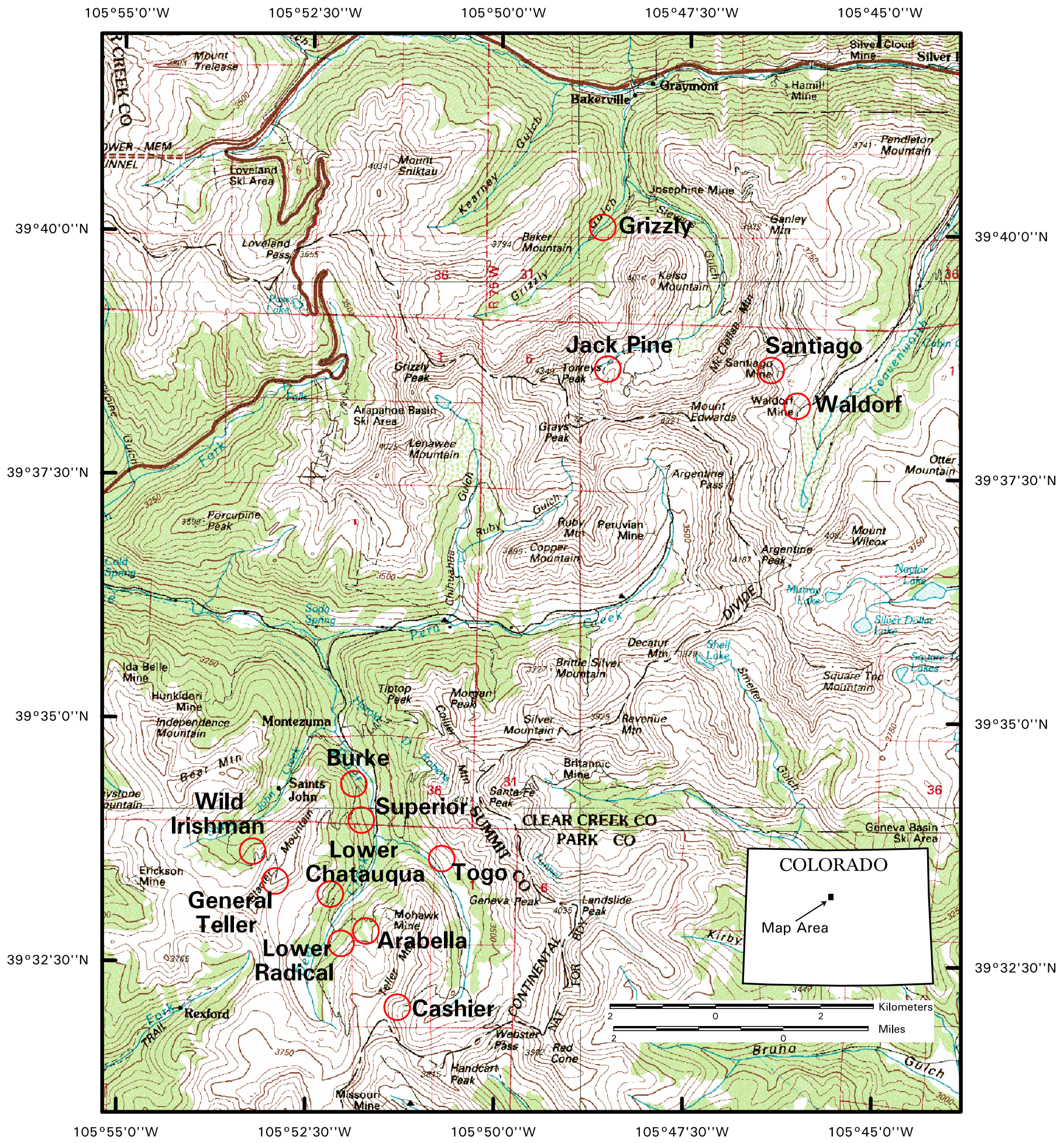

Figure 1. Location map for 13 mine dumps sampled for this study. 
Table 1. Mine wastes sampled, their location, and host-rock formation.

\begin{tabular}{lll}
\hline Mine name & Drainage basin & \multicolumn{1}{c}{ Host rock } \\
\hline Arabella & Deer Creek & Swandyke hornblende gneiss \\
Lower Radical & Deer Creek & Swandyke hornblende gneiss \\
Lower Chatauqua & Deer Creek & Swandyke hornblende gneiss \\
General Teller & Deer Creek & Swandyke hornblende gneiss with pegmatite \\
Cashier & Upper Snake River & Swandyke hornblende gneiss \\
Togo & Upper Snake River & Idaho Springs Formation \\
Burke & Snake River* & Swandyke hornblende gneiss \\
Superior & Snake River* & Swandyke hornblende gneiss \\
Wild Irishman & Saints John & Swandyke hornblende gneiss \\
Grizzly & Grizzly Gulch & Idaho Springs Formation \\
Jack Pine & Stevens Gulch & Idaho Springs Formation \\
Waldorf & Leavenworth Creek & Idaho Springs Formation and rhyolytic \\
& & intrusive rocks \\
Santiago & Leavenworth Creek & Idaho Springs Formation and rhyolytic \\
& & intrusive rocks \\
\hline
\end{tabular}

* Below confluence with Deer Creek.

in figure 1. Specific information about each site-including the mine name, drainage basin in which the mine-wastes are located, and the host rock in which the mines reside—is given in table 1.

\section{Sample Media}

For this study, focus was applied to the leachate geochemical profile of the outer "skin" or upper $15 \mathrm{~cm}$ of the surface of the mine-waste pile. It is important to characterize the geochemical potential of the outer skin of mine-waste piles because the skin of a mine-waste pile is very geochemically reactive. This reactivity is due to contact with the atmosphere. In the case of these historical mine-waste piles, the outer surface of the piles have been exposed to atmospheric oxygen and severe weathering for extended periods of time. Weathering processes include wide temperature fluctuations, innumerable freeze/thaw cycles, high winds, solar influences, biologic activity, and precipitation in all forms. As a result of these factors, wet/dry cycles cause repeated leaching, that, in turn, produce continuous wicking, rinsing, and reformation of soluble mineral salts and other secondary minerals. At the same time, the body of the pile acts as a huge sulfide reservoir, providing acid and metals to replenish material leached from the surface.

\section{Sample Collection}

Mine-wastes were sampled using a composite sampling technique (Smith and others, 2000). The sampling procedure consisted of collecting at least 30 random samples from a mine-waste pile using a steel trowel and a plastic bucket. Coarse material (material that was larger than the top knuckle of the thumb) was discarded during collection. All increments were put into a 5-gallon plastic bucket and mixed. If the sample was wet, it was first air-dried on a plastic tarp and then mixed. The mine-waste composite was then sieved to pass a 2 -mm stainless steel screen. The $<2$-mm fraction was saved for leaching and further analysis, and all material $>2 \mathrm{~mm}$ was discarded.

\section{Leaching Parameters}

The <2-mm mine-waste composite samples were leached using the simplified USGS field leach test described in Hageman and Briggs (2000), followed by an 18-hour end-over-end leaching test. In the USGS field leach test, $100.0 \mathrm{~g}$ of the $<2$ $\mathrm{mm}$ fraction of the composite sample was put in a plastic bottle and $2.0 \mathrm{~L}$ of deionized water was slowly added. The container was capped and shaken vigorously for 5 minutes. After shaking, the mixture was allowed to settle for $\sim 10$ minutes. Leachates produced from these tests were measured for $\mathrm{pH}$ and specific conductance and then syringe-filtered $(0.45-\mu \mathrm{m}$ pore-size nitrocellulose capsule filters). Portions of the filtrate were taken and preserved for analysis by inductively coupled plasma-atomic emission spectroscopy, inductively coupled plasma-mass spectroscopy, ion chromatography, and for mercury analysis. The containers were then recapped and placed on an end-over-end rotator for 18 hours. After rotation for 18 hours, the leachates were allowed to settle. The leachate was then sampled, measured, and preserved in the manner described above. 


\section{Analytical Methods and Procedures}

Similar analytical methods and procedures were used for all samples. Following is a brief explanation of analytical techniques and equipment used in this study.

\section{pH}

Laboratory $\mathrm{pH}$ measurements for unfiltered leachates were obtained using an Orion Model 230-A pH meter and an Orion combination $\mathrm{pH}$ electrode. The meter was calibrated prior to each set of measurements, and calibration checks were obtained on mid-range buffers between readings. For calibration to be successful, buffers must not exceed known concentration by $\pm 0.02 \mathrm{pH}$ units. The analysis of $\mathrm{pH}$ required no sample treatment, and the sample was analyzed immediately.

\section{Specific Conductance}

Laboratory measurements were made on unfiltered leachate using a Myron L portable conductivity meter (Model DC4). Prior to initial use, the meter was calibrated with commercially obtained conductivity standards. Prior to each set of observations, aliquots of commercially obtained $100-\mu \mathrm{S} / \mathrm{cm}$ and $1,000-\mu \mathrm{S} / \mathrm{cm}$ standards were checked and their values recorded. Conductivity analysis required no sample treatment, and samples were analyzed immediately.

\section{Metals Analyses}

Concentrations of metals were determined by the following methods: inductively coupled plasma-atomic emission spectroscopy (ICP-AES) (Meier and others, 1994), and inductively coupled plasma-mass spectroscopy (ICP-MS) (Lamothe and others, 1999). Preservation of the samples for metals analysis required that the sample be filtered and acidified to $\mathrm{pH} \leq 1.5$ with Ultrex II ultrapure $\mathrm{HNO}_{3}$. Maximum hold time for the sample was 180 days.

\section{NAP Analyses}

NAP (net-acid production), sometimes referred to as "net-acidity," was determined for all 13 mine-waste composites using a modification of the technique described by Lapakko and Lawrence (1993). This procedure is carried out on $1.00-\mathrm{g}$ split of finely ground ( $-200 \mathrm{mesh}$ ) material taken from each $<2$-mm mine-waste composite sample. Results are given in $\mathrm{kg} \mathrm{CaCO}_{3}$ per metric ton (parts per thousand).

\section{Sulfate Analyses}

Sulfate was determined by ICP-MS (Lamothe and others, 1999). This method required that the sample be filtered and acidified with $\mathrm{HNO}_{3}$ as described above. Maximum hold time was 180 days.

\section{Mercury Analyses}

Leachate mercury concentrations were determined by cold vapor-atomic fluorescence spectrometry (CV-AFS) (Hageman, 2002). For this method, the filtrate was acidified/ preserved with a 1-percent sodium dichromate/concentrated $\mathrm{HNO}_{3}$ solution in a ratio of 1:19 (one part sodium dichromate/ $\mathrm{HNO}_{3}$ solution to 19 parts leachate sample). Leachate samples were collected in nitric-acid-washed flint-glass bottles with Teflon-lined lids.

\section{Results and Discussion}

In this report, leachate geochemical comparisons are made (5-minute USGS field leach test vs. 18-hour leach test) for all 13 mine-waste composite samples. Complete leachate geochemical data for all sites are given in tabular form in Appendix 1. NAP results for solid mine-waste samples are given in Appendix 2. Data plots comparing leachate $\mathrm{pH}$, specific conductance, and sulfate for all 13 mine-wastes are presented (figs. 2 and 3) and discussed. In addition to comparing relative trends for all sites, plots detailing leachate geochemical data and trends for individual mine-wastes are presented in figures 4-16. Leachate geochemical summaries for individual mine-wastes are presented in Appendix 3. Data in the summaries include: site location, host rock, leachate $\mathrm{pH}$, specific-conductance trends, , sulfate, selected major-element trends, selected trace-element trends, and NAP on the solids. Finally, this paper presents, describes, and discusses three mine-waste-ranking schemes.

\section{Data}

Important note.-Concentrations presented in this paper are leachate concentrations. All samples were leached at 20:1 ratio (20 parts deionized water to 1 part solid), except for NAP, which was measured from a split of the mine-waste composite $<2$-mm solid material.

\section{Leachate Geochemical Comparisons and Trends for All Sites}

Following is a brief summary comparing selected leachate geochemistry for all 13 sites. 


\section{$\mathrm{pH}$ and Specific Conductance}

Figure 2 shows the data and trend lines for all 13 minewaste leachate samples for $\mathrm{pH}$ and specific conductance over time. In this plot, $\mathrm{pH}$ data from the 5-minute USGS field leach test are compared to $\mathrm{pH}$ data from the 18-hour leach test. Leachate $\mathrm{pH}$ values went down over time in leachate produced from the Togo, Arabella, Lower Radical, and Jack Pine mine-waste composites. The lowest $\mathrm{pH}$ (3.0) was found in leachate from the Togo mine-waste (located in the upper Snake River watershed). However, the greatest drop in $\mathrm{pH}$ over time occurred in the leachate from the Lower Radical mine-waste (upper Deer Creek watershed), which dropped from $\mathrm{pH} 4.8$ in the 5-minute leachate to $\mathrm{pH} 4.6$ after 18 hours $(-0.2 \mathrm{pH}$ units). Other mine-waste leachates that dropped in $\mathrm{pH}$ over time were: Togo (-0.1), Arabella (-0.1), and the Jack Pine $(-0.1)$. The largest increase in $\mathrm{pH}$ occurred in leachate from the Santiago mine-waste composite (Leavenworth Creek watershed), which showed a spike in $\mathrm{pH}$ from 3.6 after 5 minutes to 5.2 after 18 hours ( $+1.6 \mathrm{pH}$ units). $\mathrm{pH}$ also increased over time in leachate from the Wild Irishman $(+1.1)$, Lower Chatauqua (+0.4), Superior and Cashier $(+0.3)$, Waldorf $(+0.2)$, and the Burke and General Teller $(+0.1)$. The $\mathrm{pH}$ in leachate from the Grizzly mine-waste stayed the same over time.

$\mathrm{pH}$ trends produced from the 5-minute leach test correlated to $\mathrm{pH}$ trends produced from the 18-hour leach test.

Figure 2 also shows specific conductance data and trends for all 13 mine-waste composites. 18-hour leachate values for specific conductance ranged from $8.78 \mu \mathrm{S} / \mathrm{cm}$ in the General Teller leachate (located in Upper Deer Creek watershed) to $1,730 \mu \mathrm{S} / \mathrm{cm}$ for leachate from the Santiago mine-waste (located in the Leavenworth Creek/Clear Creek watershed). Other leachates with high specific conductance were the Waldorf (located in the Leavenworth Creek/Clear Creek watershed) $(1,092 \mu \mathrm{S} / \mathrm{cm})$, and the Togo $(718 \mu \mathrm{S} / \mathrm{cm})$ (located in the Upper Snake River watershed).

Generally, the leachate specific conductance trend line for the 13 leachates corresponded very well to the trend for $\mathrm{pH}$. That is, leachate samples with higher $\mathrm{pH}$ had lower specific conductivities and leachates with lower $\mathrm{pH}$ values had higher conductivities. Also, the relatively simple 5-minute test does a good job portraying the general trend for specific conductance for these 13 sites.

\section{Sulfate}

Figure 3 shows the 5-minute and 18-hour leachate sulfate concentration, and the sulfate trend for all 13 sites. Sulfate concentration was generally low $(<200 \mathrm{mg} / \mathrm{L})$ at 11 of the 13 sites. However, the Waldorf and Santiago mine-wastes, located in the Leavenworth Creek/Clear Creek watershed, had much higher sulfate concentration, with $443 \mathrm{mg} / \mathrm{L}$ in the 5-minute Waldorf leachate and $736 \mathrm{mg} / \mathrm{L}$ sulfate in the 5-minute Santiago leachate.

Like many of the other geochemical data, sulfate data

\section{Leachate $\mathrm{pH}$ and Specific Conductance (5-minute vs 18-hour)}

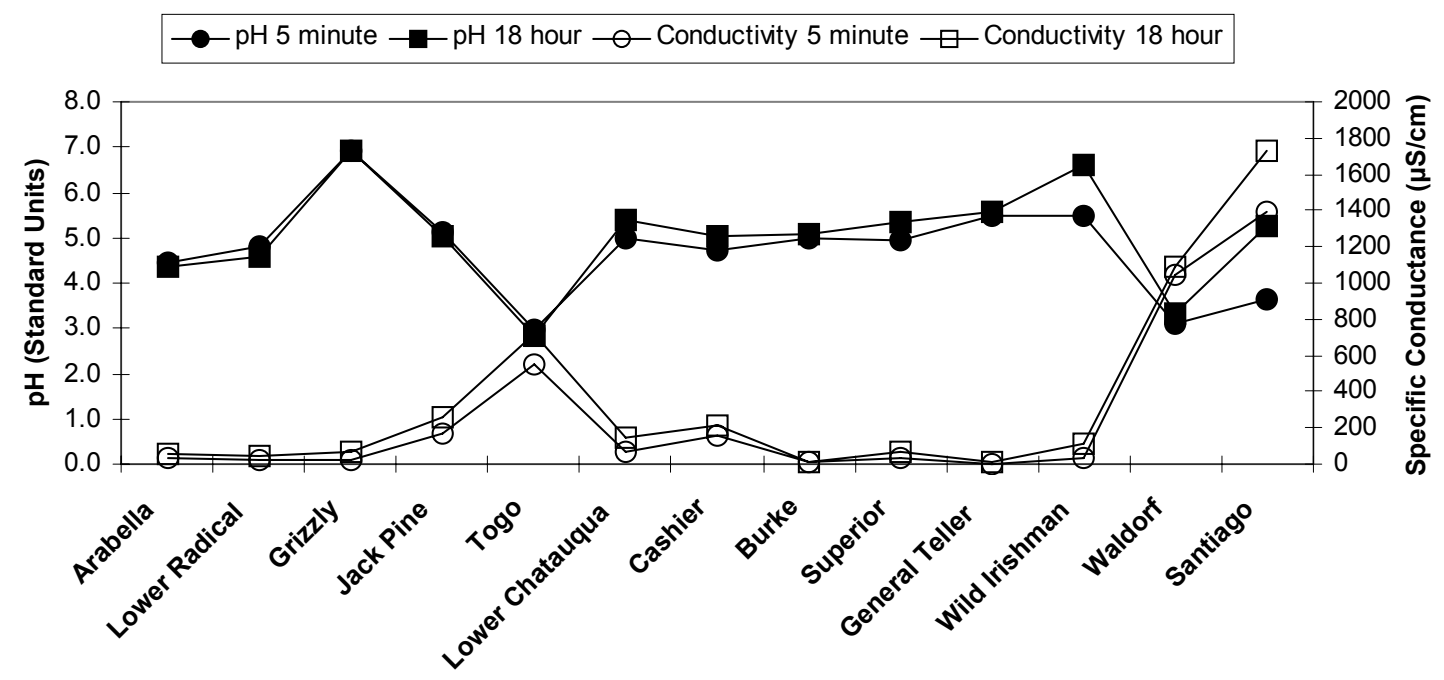

Figure 2. Comparison of leachate $\mathrm{pH}$ and specific conductance data ( 5 minute and 18 hour) for 13 mine-wastes included in this study. 


\section{Leachate Sulfate Concentration for Thirteen Mine Dumps: 5-Minute vs 18-Hour}

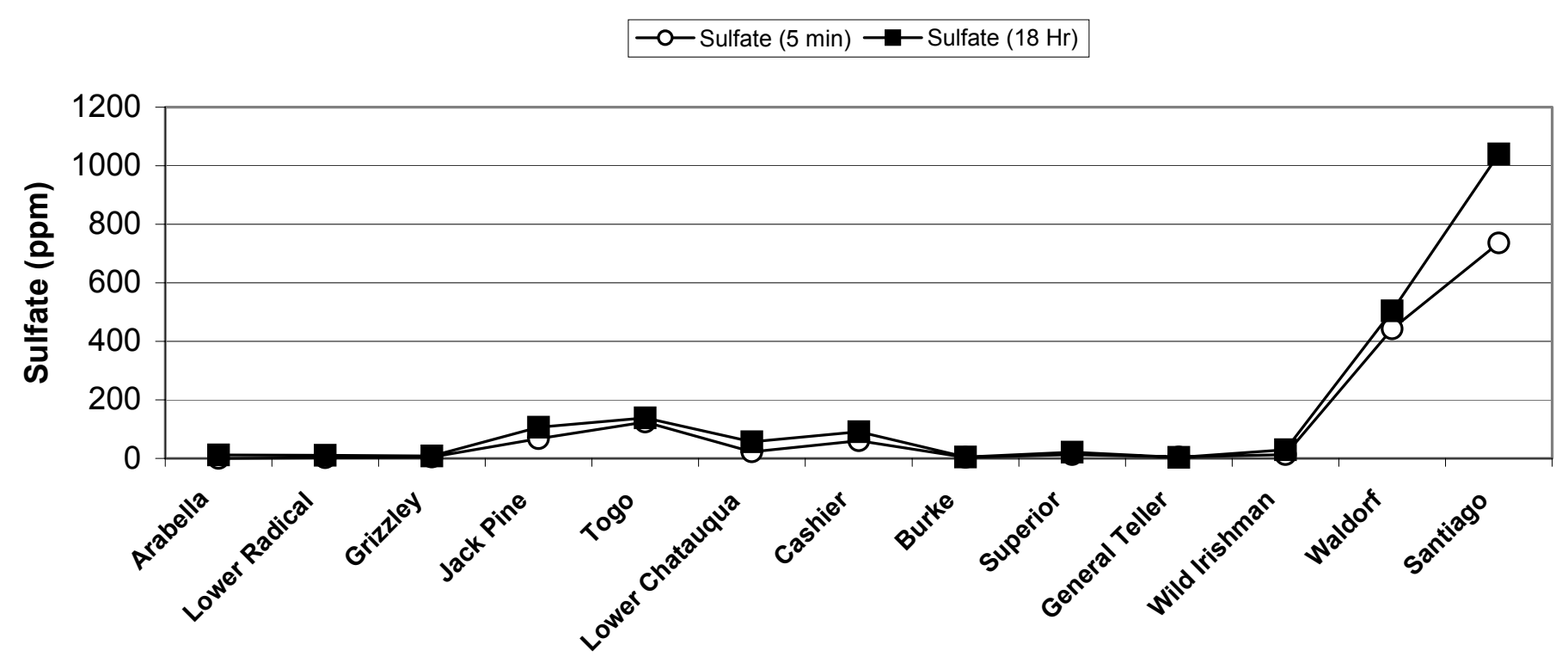

Figure 3. Comparison of leachate sulfate data ( 5 minute and 18 hour) for 13 mine-wastes included in this study.

produced using the simple 5-minute USGS field leach test gives an accurate indication for the sulfate trend produced after 18 hours. This comparison indicates that leachate sulfate trends are fairly predictable and that none of the samples fell out of line or changed much during the extended leaching period. There was not much change in sulfate concentration in the leachate over time.

\section{Geochemical Data for Individual Sites}

In figures 4-16, plots are presented for selected leachate geochemical data for each site. Each figure has three plots comparing leachate geochemistry for both the 5-minute and 18-hour leaches. Data presented includes: $A$, selected major elements; $B$, selected trace metals; and $C, \mathrm{pH}$, and specific conductance. The plots provide a visual depiction of the data so that geochemical trends are more easily seen.

\section{Mine-Waste Rankings}

The following tables show the relative ranking of all mine-wastes included in this study. These rankings were established after compiling and analyzing the leachate geochemical data. This simple ranking scheme was devised in order to rank each mine-waste relative to one another, for their potential to release acid, certain metals, and other constituents into the environment should runoff occur from the mine-waste pile. Although many factors go into making a mine-waste leachate potentially toxic to the environment, for the purposes of this investigation, I used what I consider major contributing factors for potential toxicity. These factors are leachate $\mathrm{pH}$, leachate conductivity, leachate sulfate, and, finally, the sum of concentrations of selected leachate metals ( $\mathrm{Al}, \mathrm{Cd}, \mathrm{Cu}, \mathrm{Fe}$, $\mathrm{Mn}, \mathrm{Ni}, \mathrm{Pb}$, and $\mathrm{Zn}$ ). For this ranking procedure, each minewaste leachate was ranked for each of these four parameters. Each site was given a rank ranging from 1 to 13 (13 is the total number of sites included in this study) for each factor listed above. A rank of 1 represents the worst site (most impacted) for that particular factor, whereas a rank of 13 represents the least impacted site for that factor. As an example, a minewaste-producing leachate with the lowest $\mathrm{pH}$ of all 13 sites would get a ranking of " 1 ." If the same mine-waste leachate were 5 th highest in leachate conductivity, it would receive a " 5 " for that parameter. The same leachate would be ranked for sulfate and sum of metals (listed above). Cumulative results from all these tests would then be totaled. After all sites are tallied in this manner, the totals for all sites are ranked. The mine-waste leachate with the lowest cumulative score would then be ranked first in the probability that, should runoff occur, its effluent would have the most likely possibility of negatively affecting water quality should its effluent reach a water body. All other sites are ranked accordingly. 

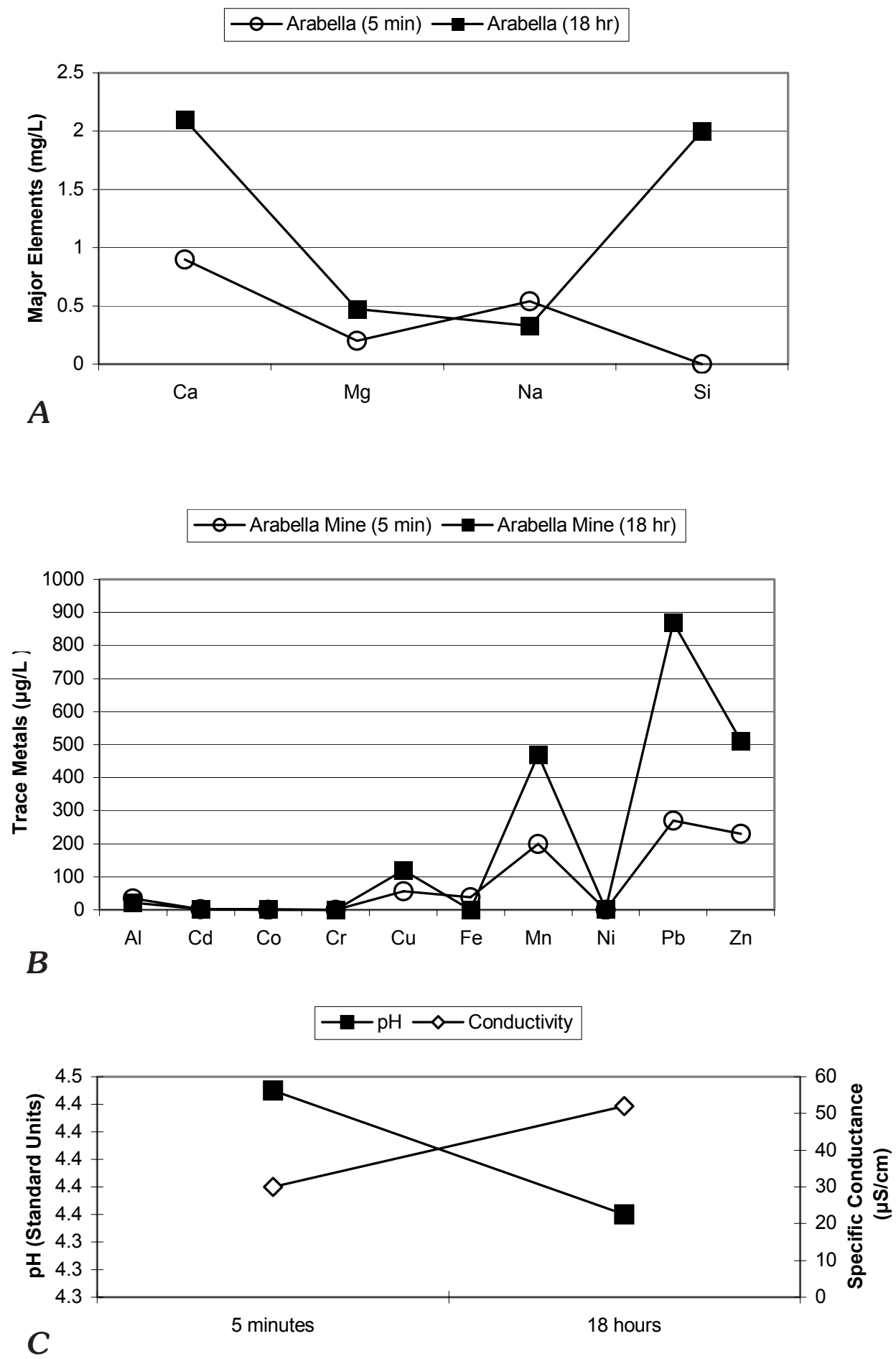

Figure 4. Arabella mine-waste leachate geochemistry trends (5 minutes vs. 18 hours) for $A$. selected major elements (ICP-AES); $B$, selected trace metals (ICP-MS); and $C$, pH and specific conductance. 

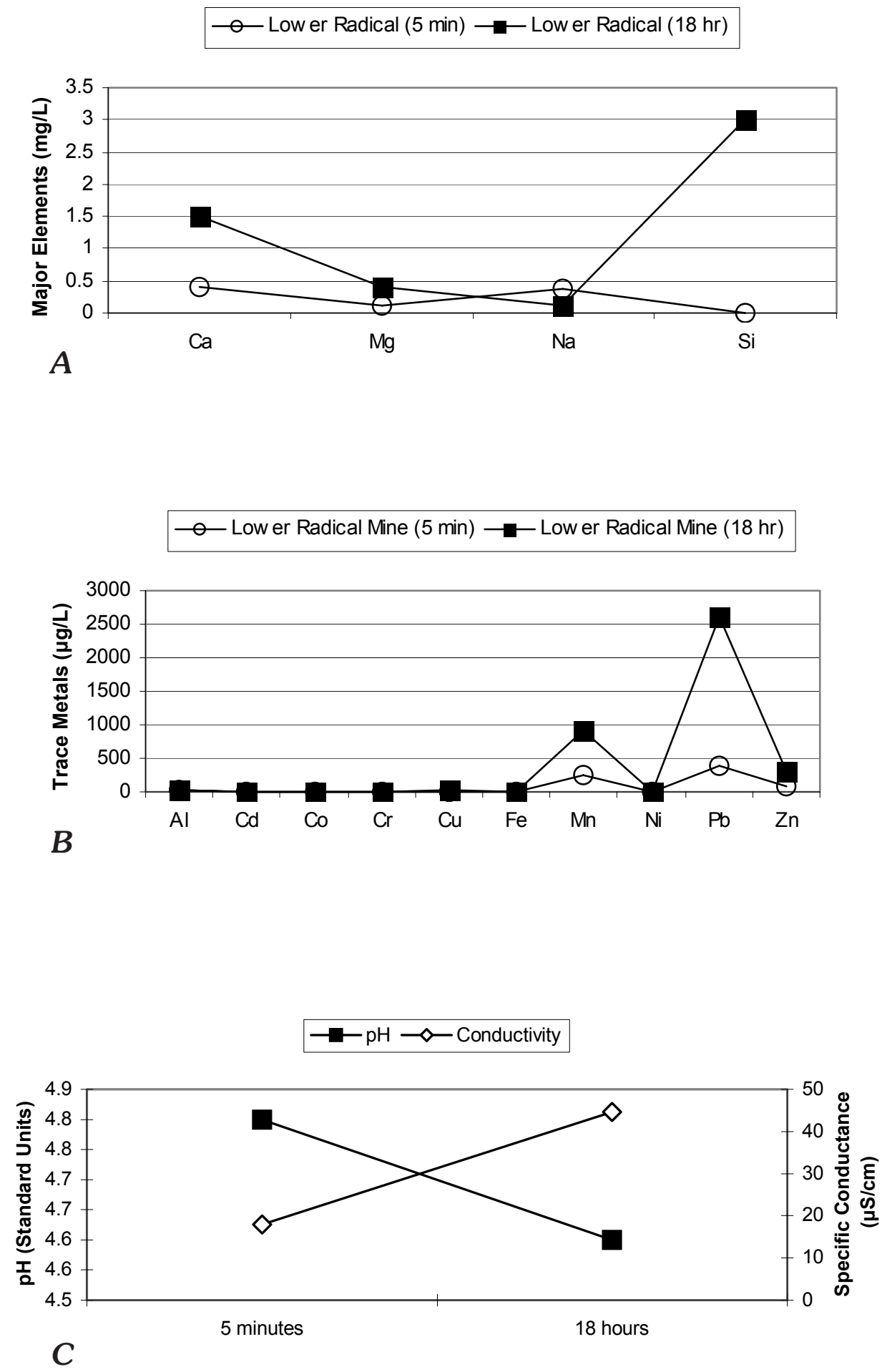

Figure 5. Lower Radical mine-waste leachate geochemistry trends (5 minutes vs. 18 hours) for $A$, selected major elements (ICP-AES); $B$, selected trace metals (ICP-MS); and $C$, $\mathrm{pH}$ and specific conductance. 

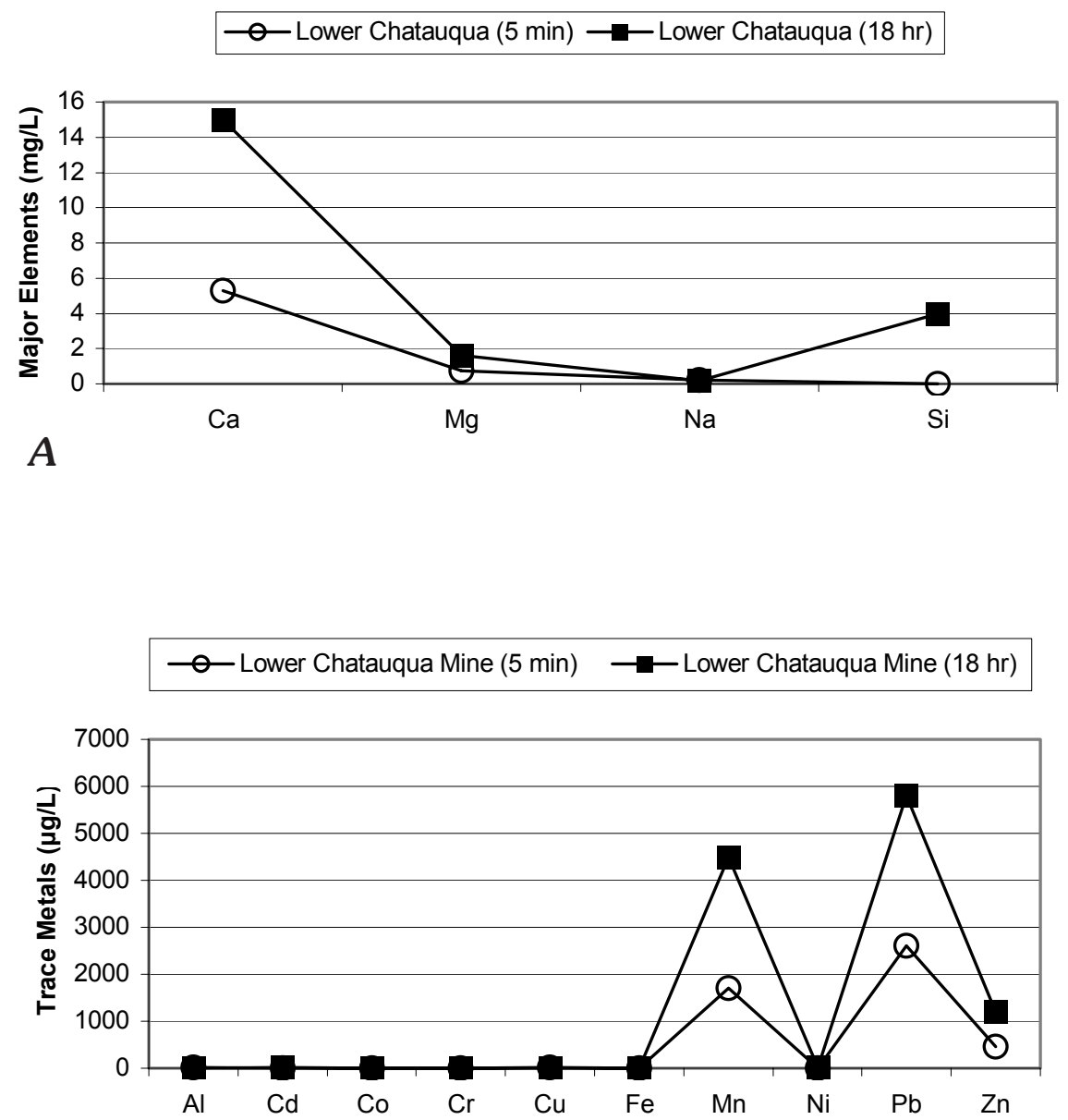

B

$\neg-\mathrm{pH} \diamond$ Conductivity

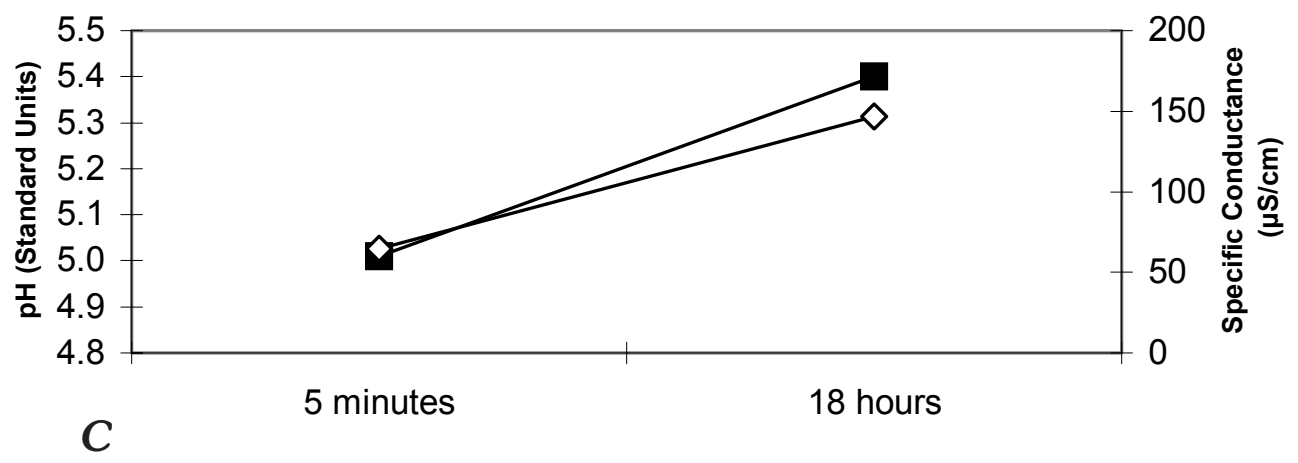

Figure 6. Lower Chatauqua mine-waste leachate geochemistry trends (5 minutes vs. 18 hours) for $A$. selected major elements (ICP-AES); $B$, selected trace metals (ICP-MS); and $C$, pH and specific conductance. 


\section{- - General Teller $(5 \mathrm{~min}) \longrightarrow$-General Teller $(18 \mathrm{hr})$}

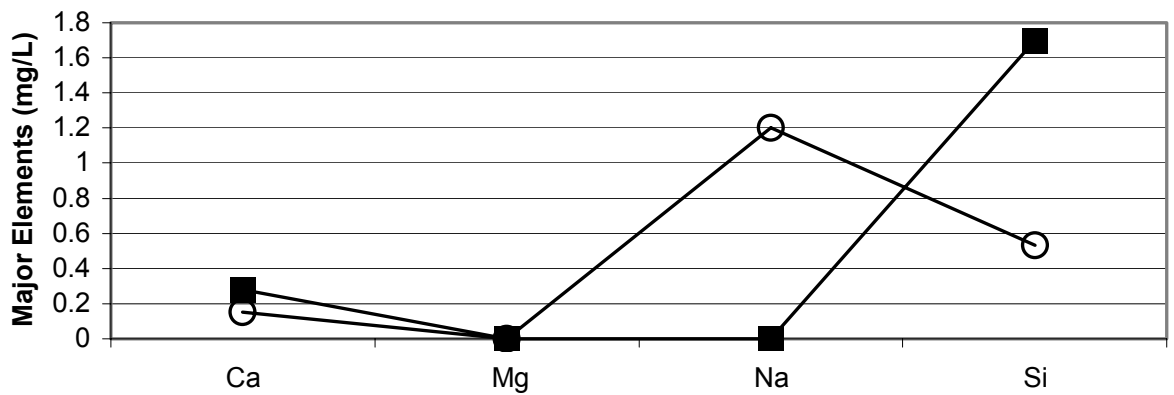

A

- - General Teller Mine (5 min) $\longrightarrow$-General Teller Mine (18 Hr)

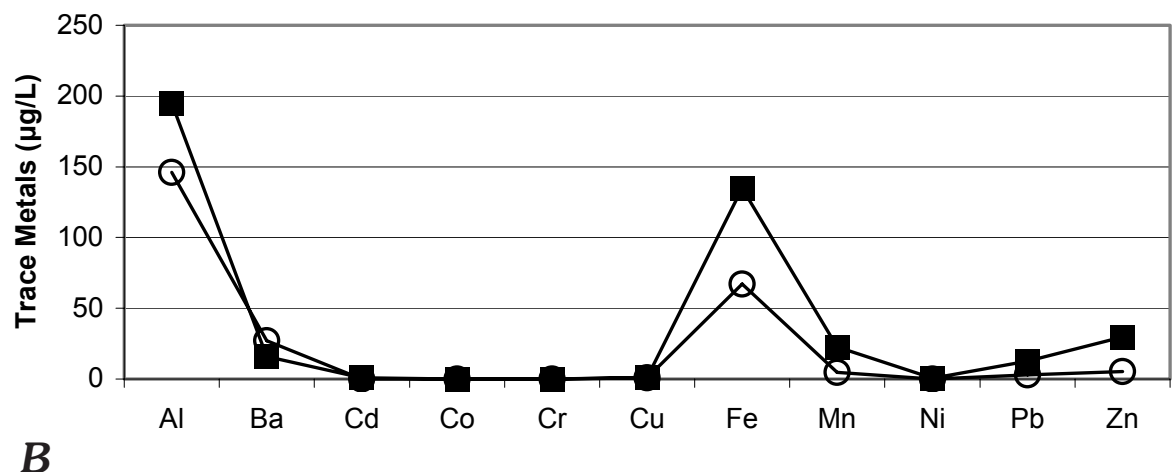

$\neg-\mathrm{pH} \leadsto$ Conductivity

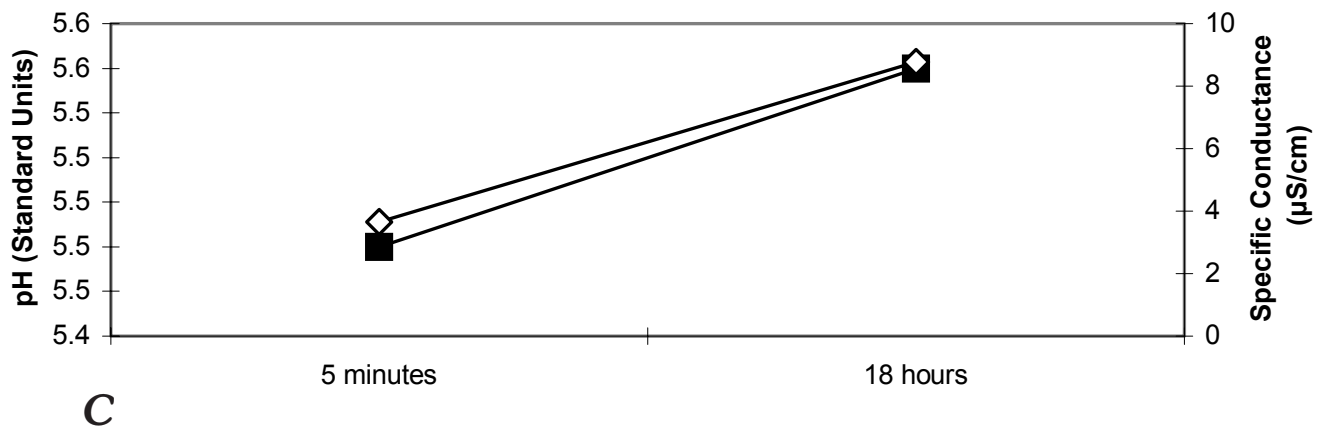

Figure 7. General Teller mine-waste leachate geochemistry trends (5 minutes vs. 18 hours) for $A$. selected major elements (ICP-AES); $B$, selected trace metals (ICP-MS); and $C, \mathrm{pH}$ and specific conductance. 

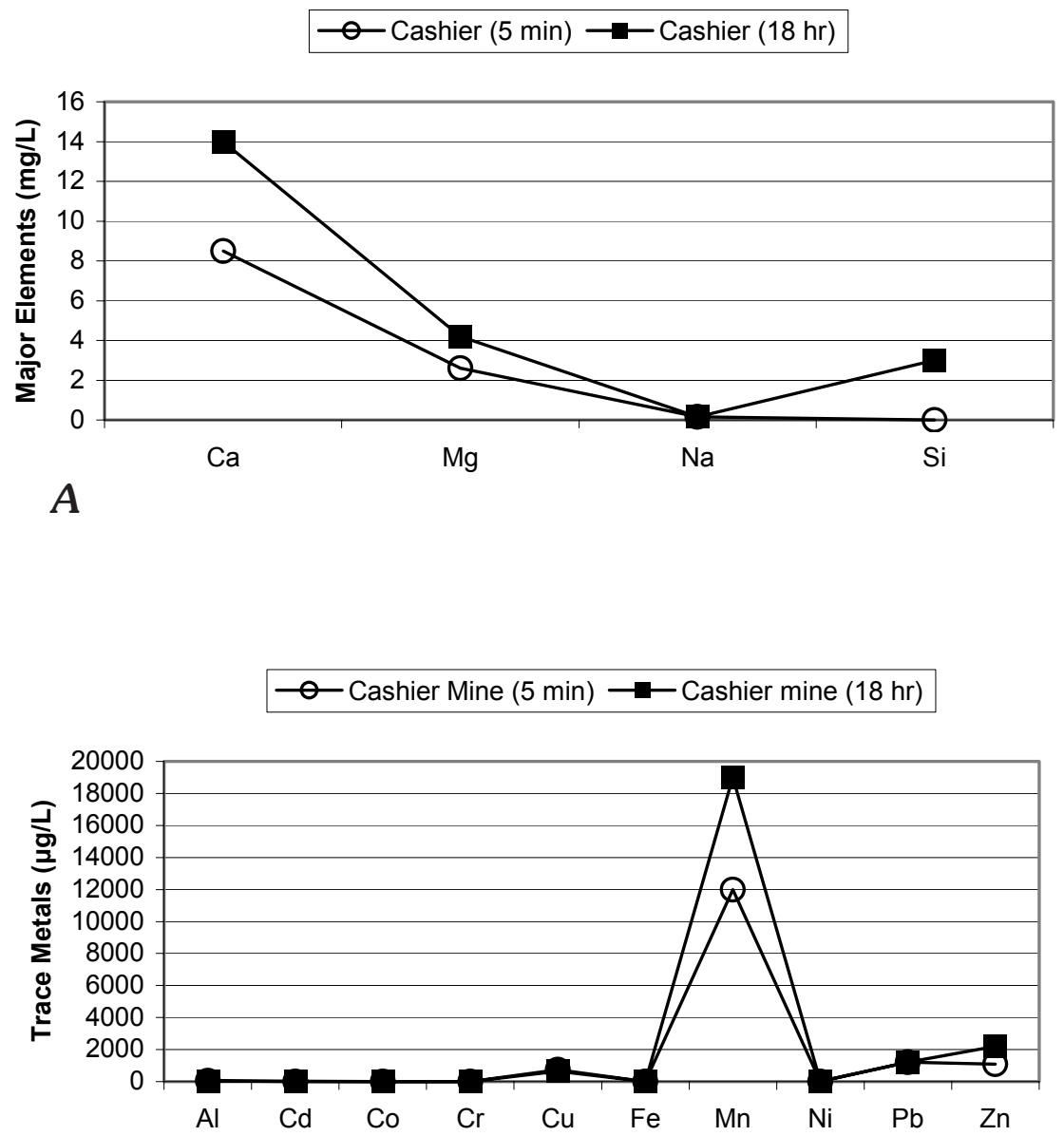

$B$

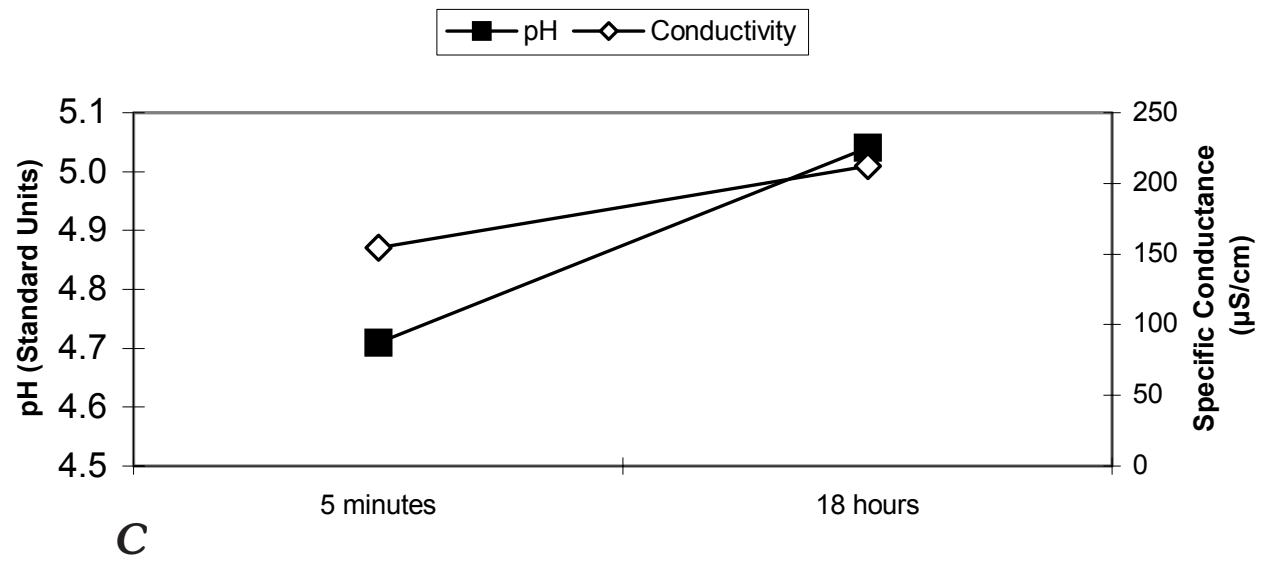

Figure 8. Cashier mine-waste leachate geochemistry trends ( 5 minutes vs. 18 hours) for $A$. selected major elements (ICP-AES); $B$, selected trace metals (ICP-MS); and $C$, pH and specific conductance. 


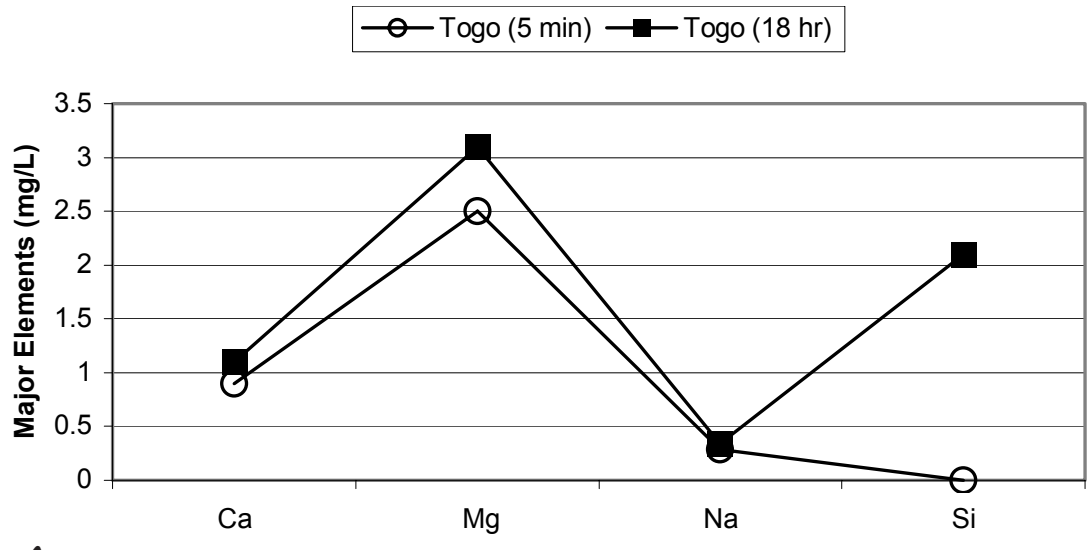

A

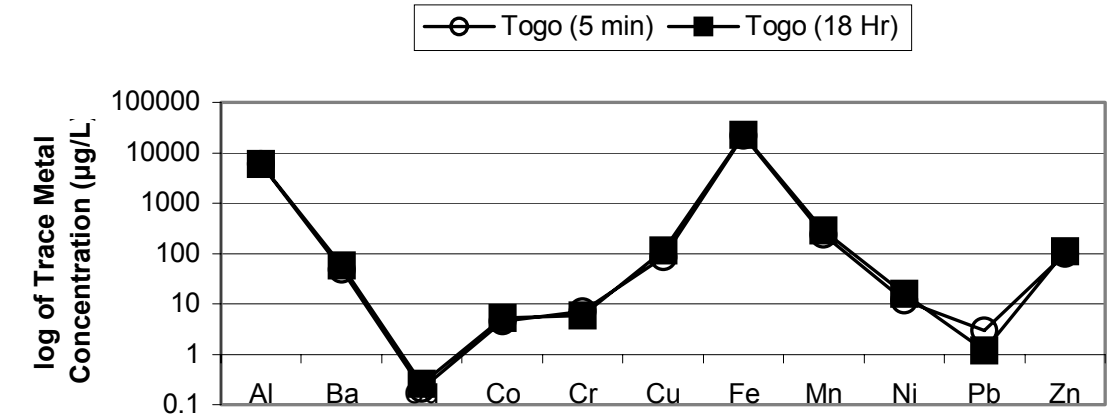

B

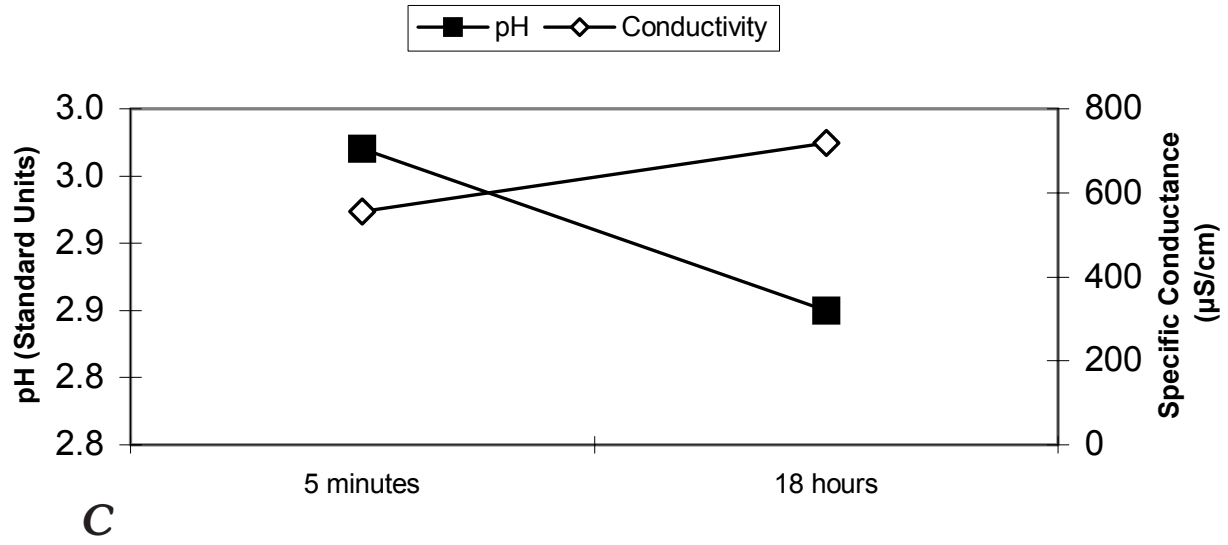

Figure 9. Togo mine-waste leachate geochemistry trends ( 5 minutes vs. 18 hours) for $A$. selected major elements (ICP-AES); $B$, selected trace metals (ICP-MS); and $C, \mathrm{pH}$ and specific conductance . 

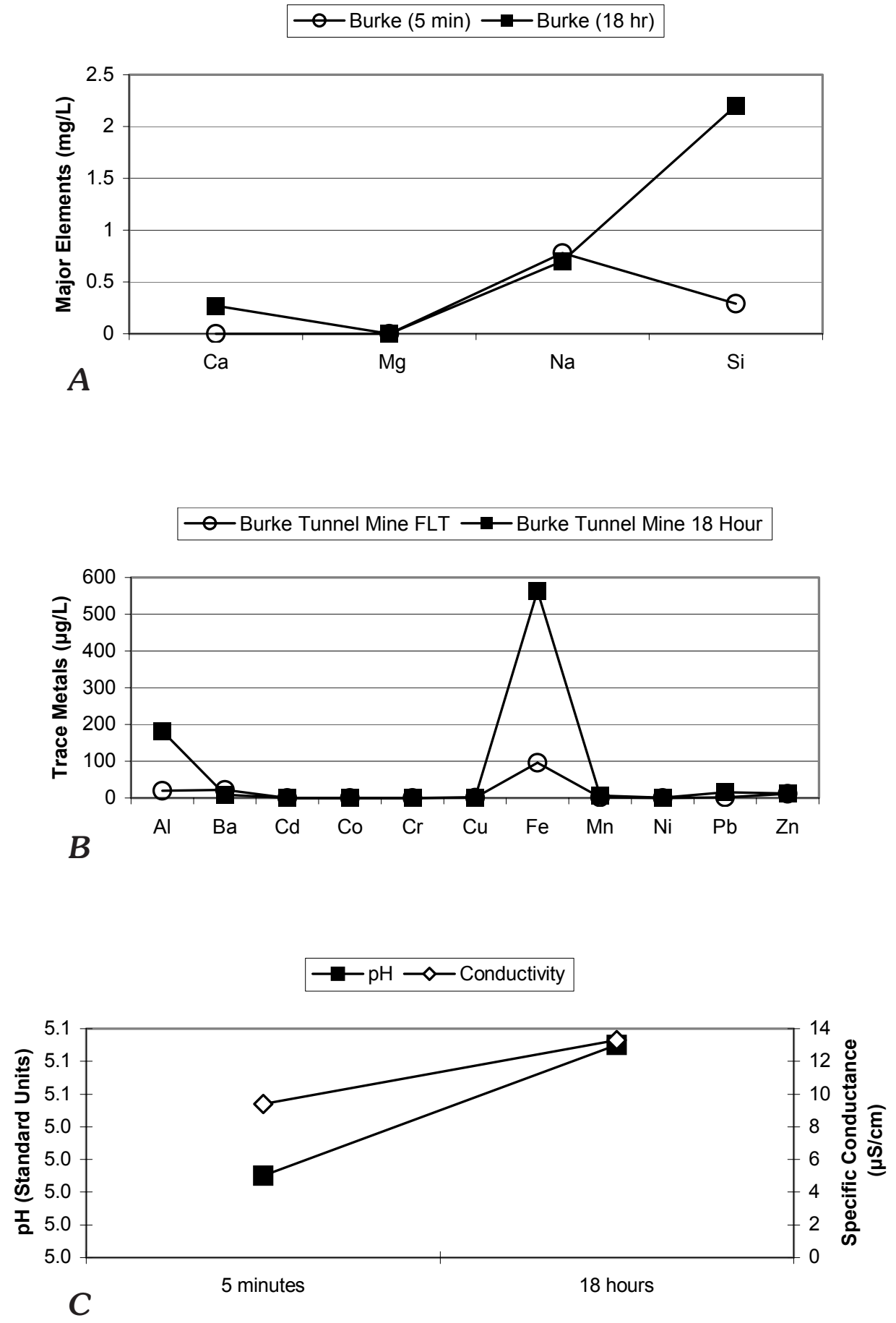

Figure 10. Burke mine-waste leachate geochemistry trends ( 5 minutes vs. 18 hours) for $A$. selected major elements (ICP-AES); $B$, selected trace metals (ICP-MS); and $C$, pH and specific conductance. 


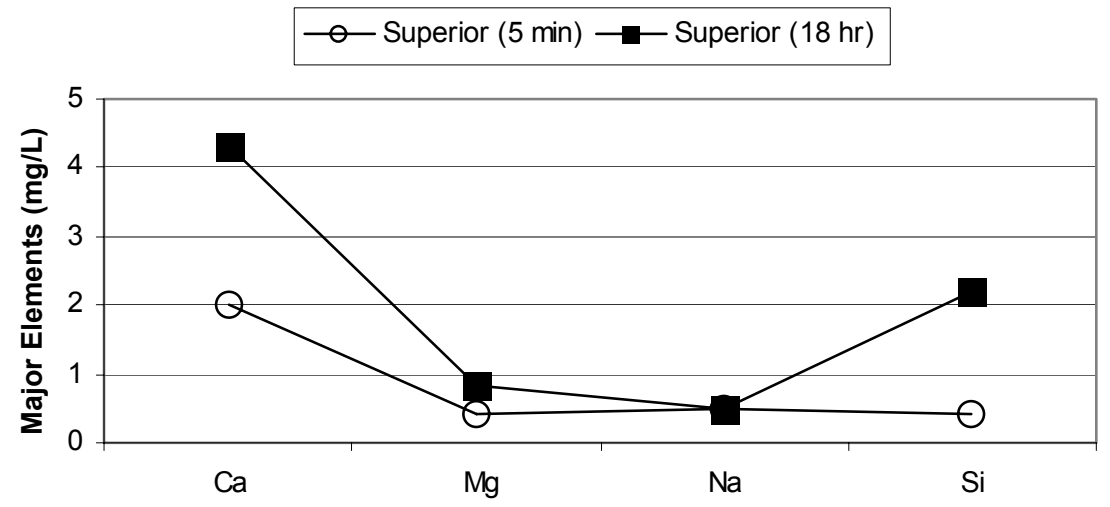

$A$
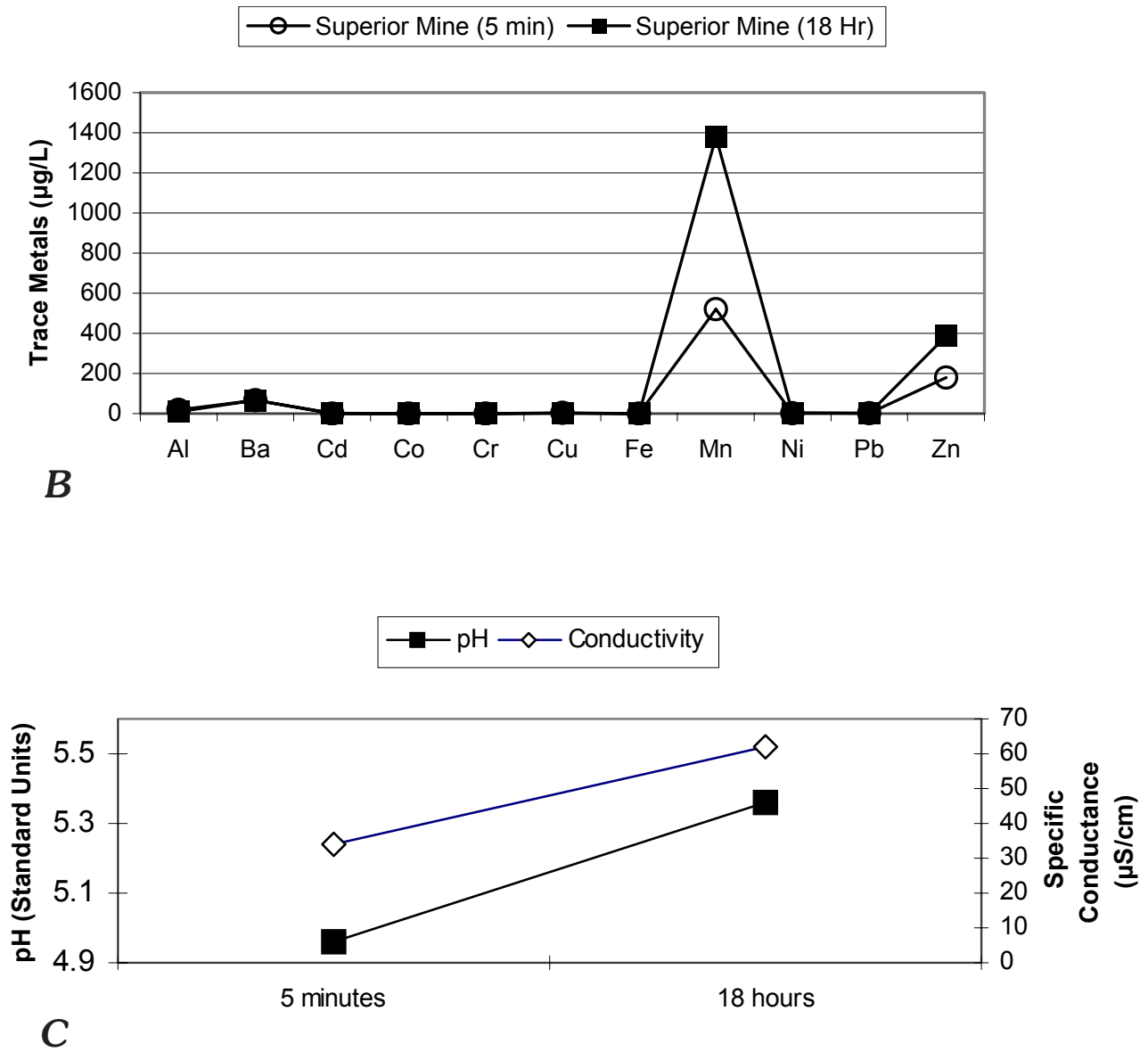

Figure 11. Superior mine-waste leachate geochemistry trends (5 minutes vs. 18 hours) for $A$. selected major elements (ICP-AES); $B$, selected trace metals (ICP-MS); and $C$, pH and specific conductance. 

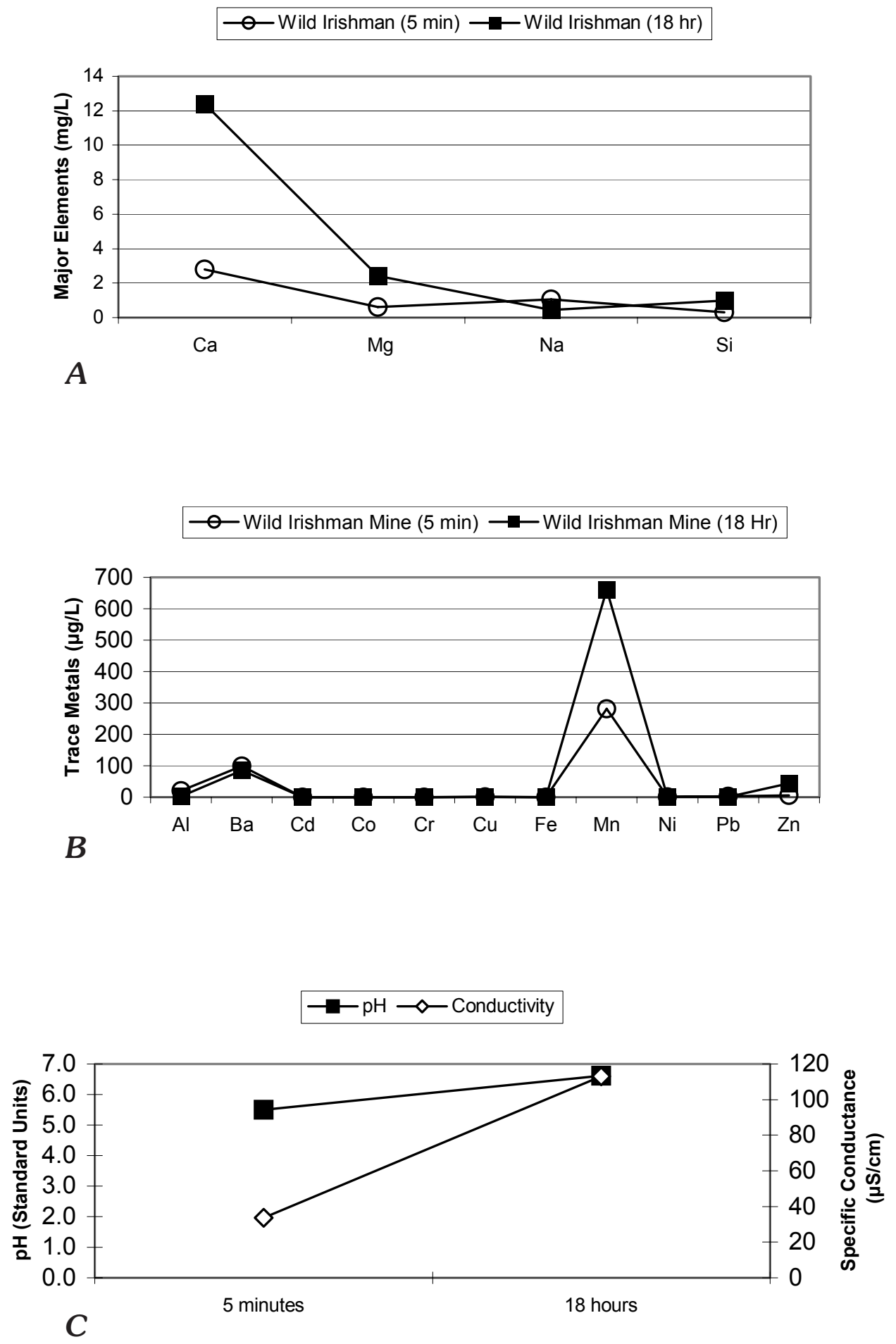

Figure 12. Wild Irishman mine-waste leachate geochemistry trends (5 minutes vs. 18 hours) for $A$. selected major elements (ICP-AES); $B$, selected trace metals (ICP-MS); and $C$, $\mathrm{pH}$ and specific conductance. 


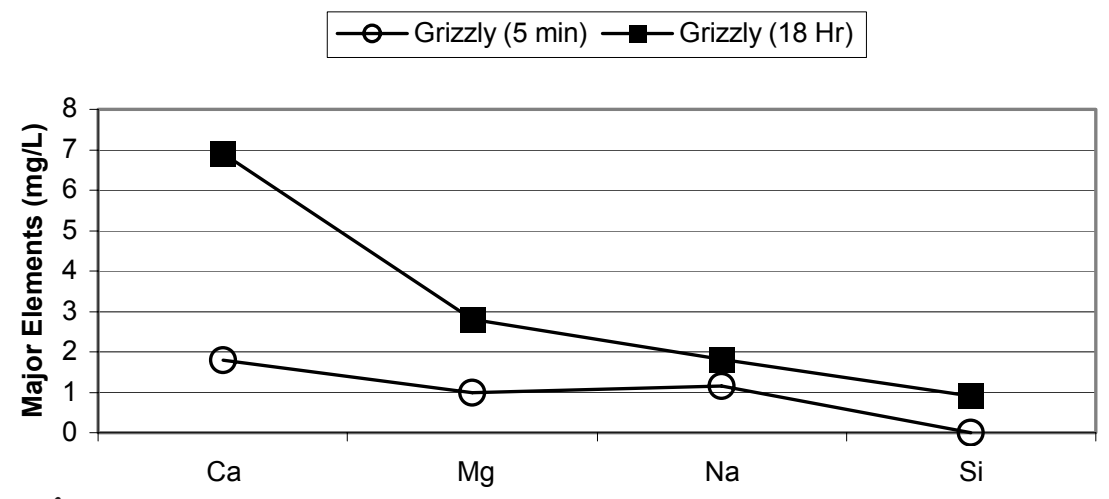

A
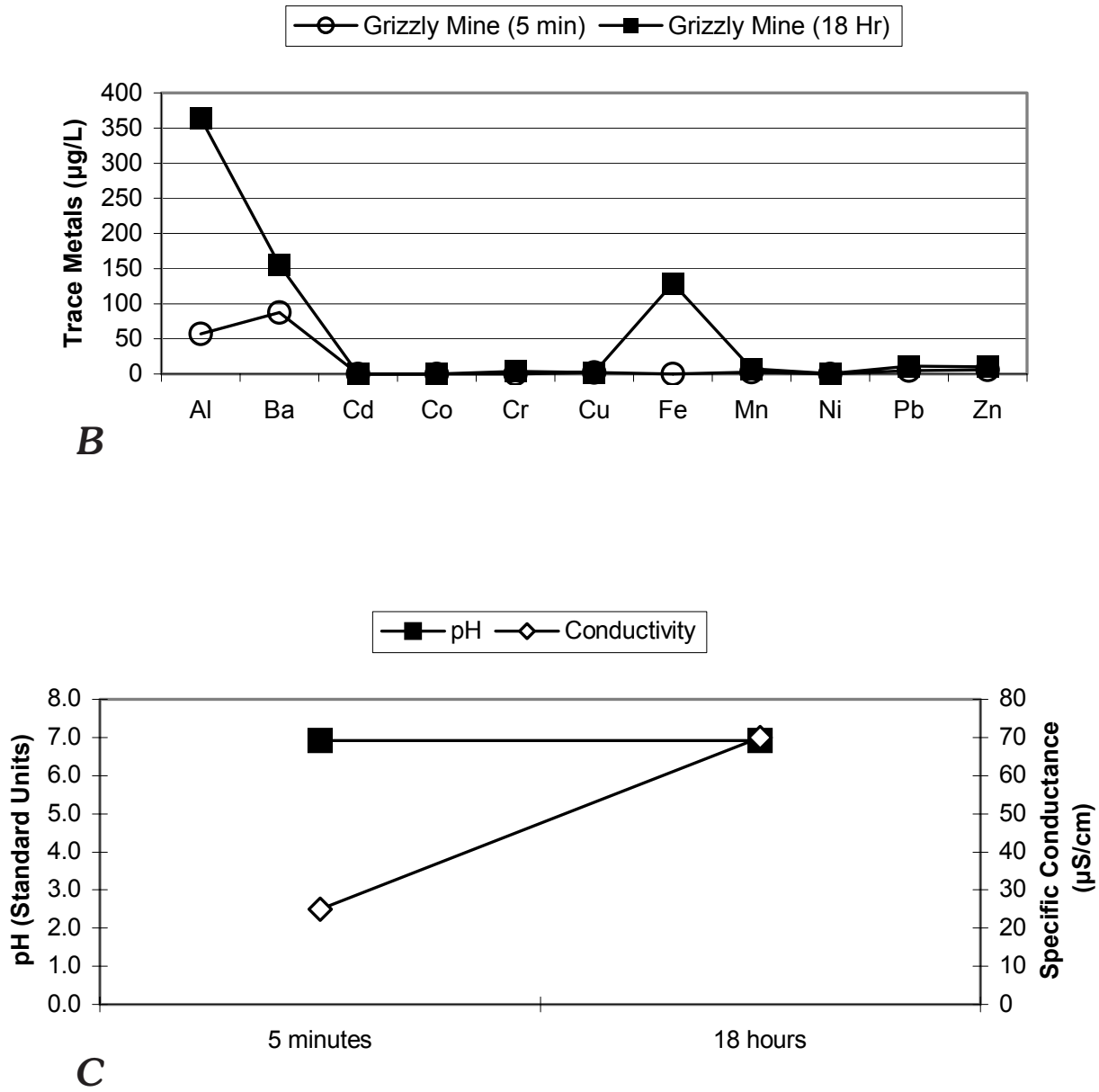

Figure 13. Grizzly mine-waste leachate geochemistry trends (5 minutes vs. 18 hours) for $A$. selected major elements (ICP-AES); $B$, selected trace metals (ICP-MS); and $C$, pH and specific conductance. 


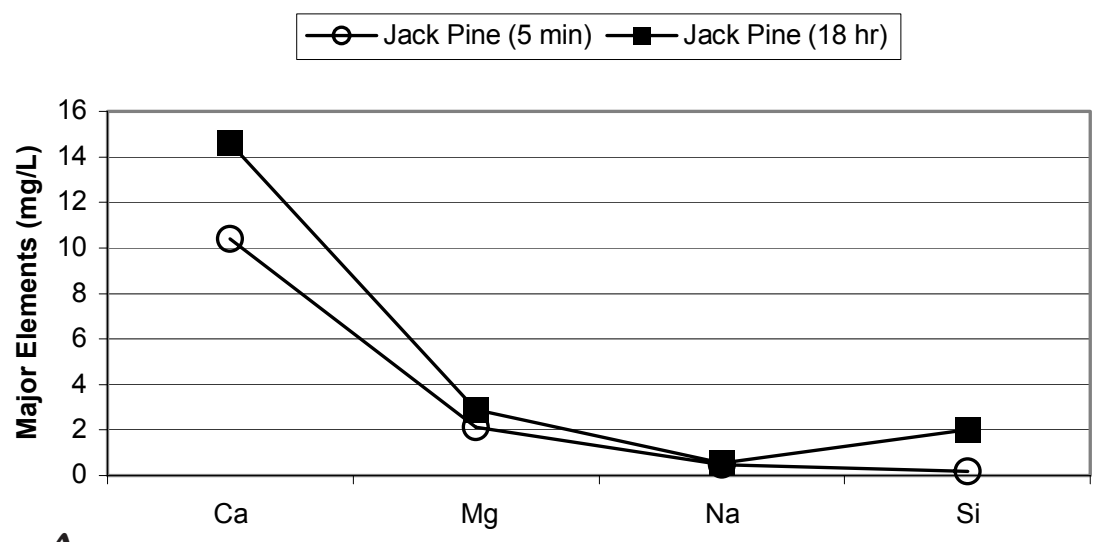

A
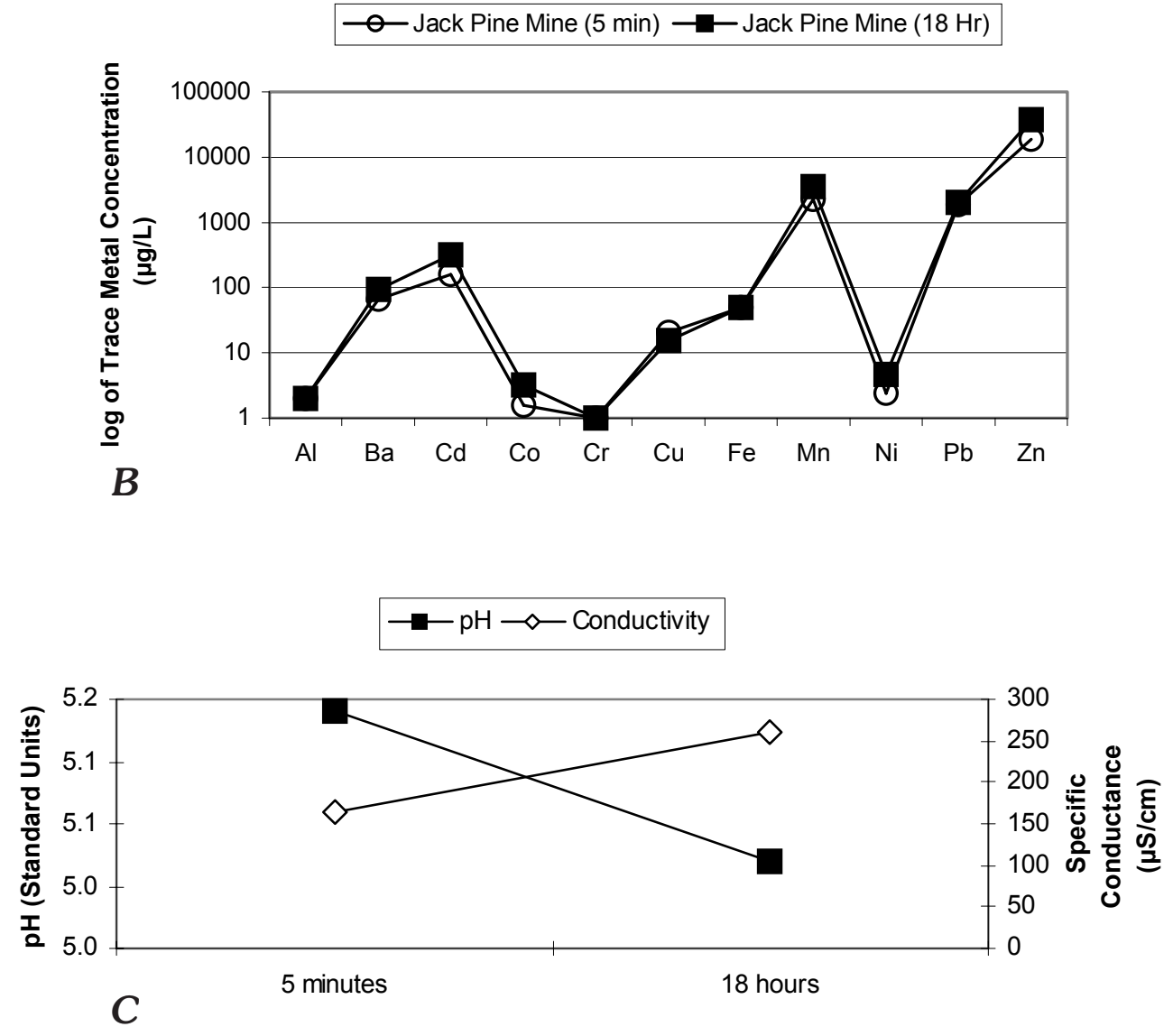

Figure 14. Jack Pine mine-waste leachate geochemistry trends (5 minutes vs. 18 hours) for $A$. selected major elements (ICP-AES); $B$, selected trace metals (ICP-MS); and $C, \mathrm{pH}$ and specific conductance . 


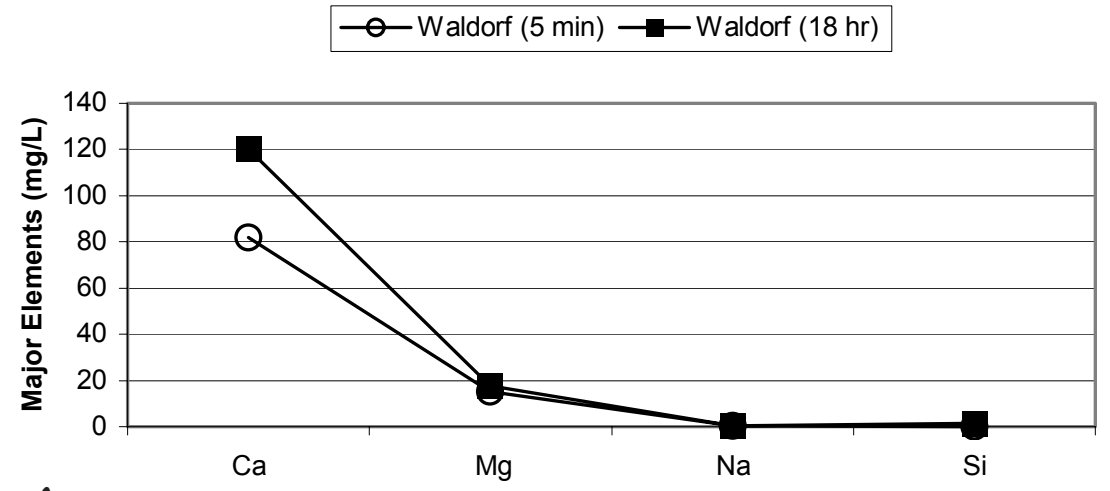

A

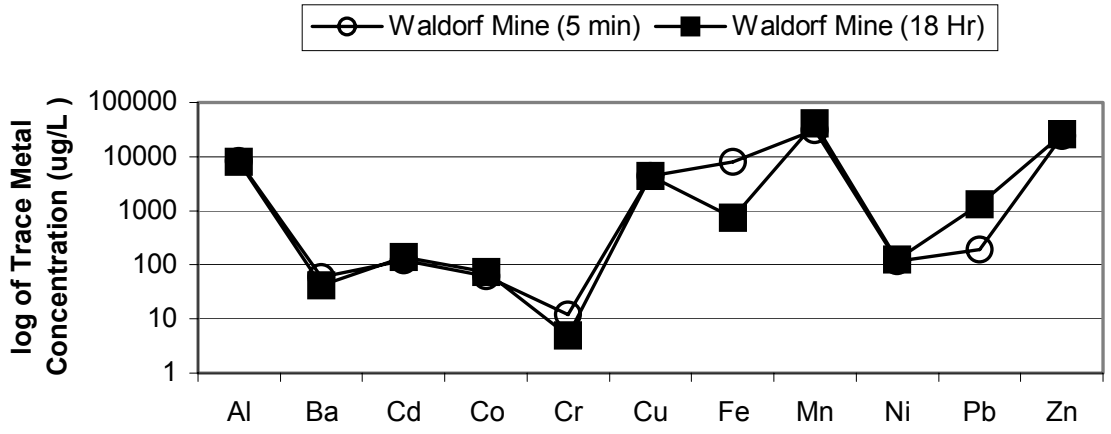

$B$

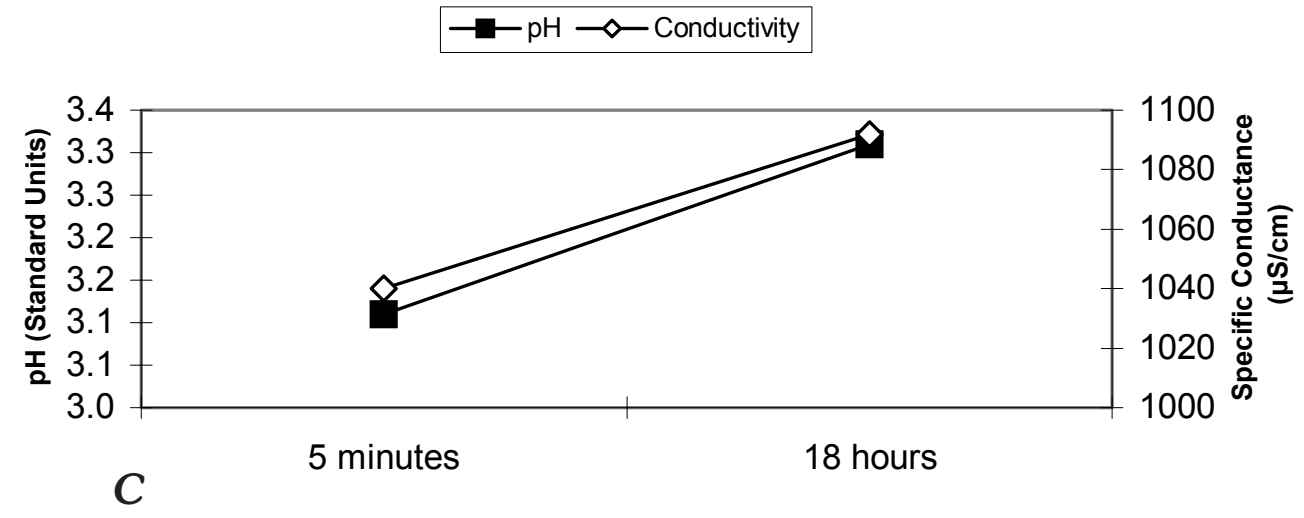

Figure 15. Waldorf mine-waste leachate geochemistry trends ( 5 minutes vs. 18 hours) for $A$. selected major elements (ICP-AES); $B$, selected trace metals (ICP-MS); and $C, \mathrm{pH}$ and specific conductance . 

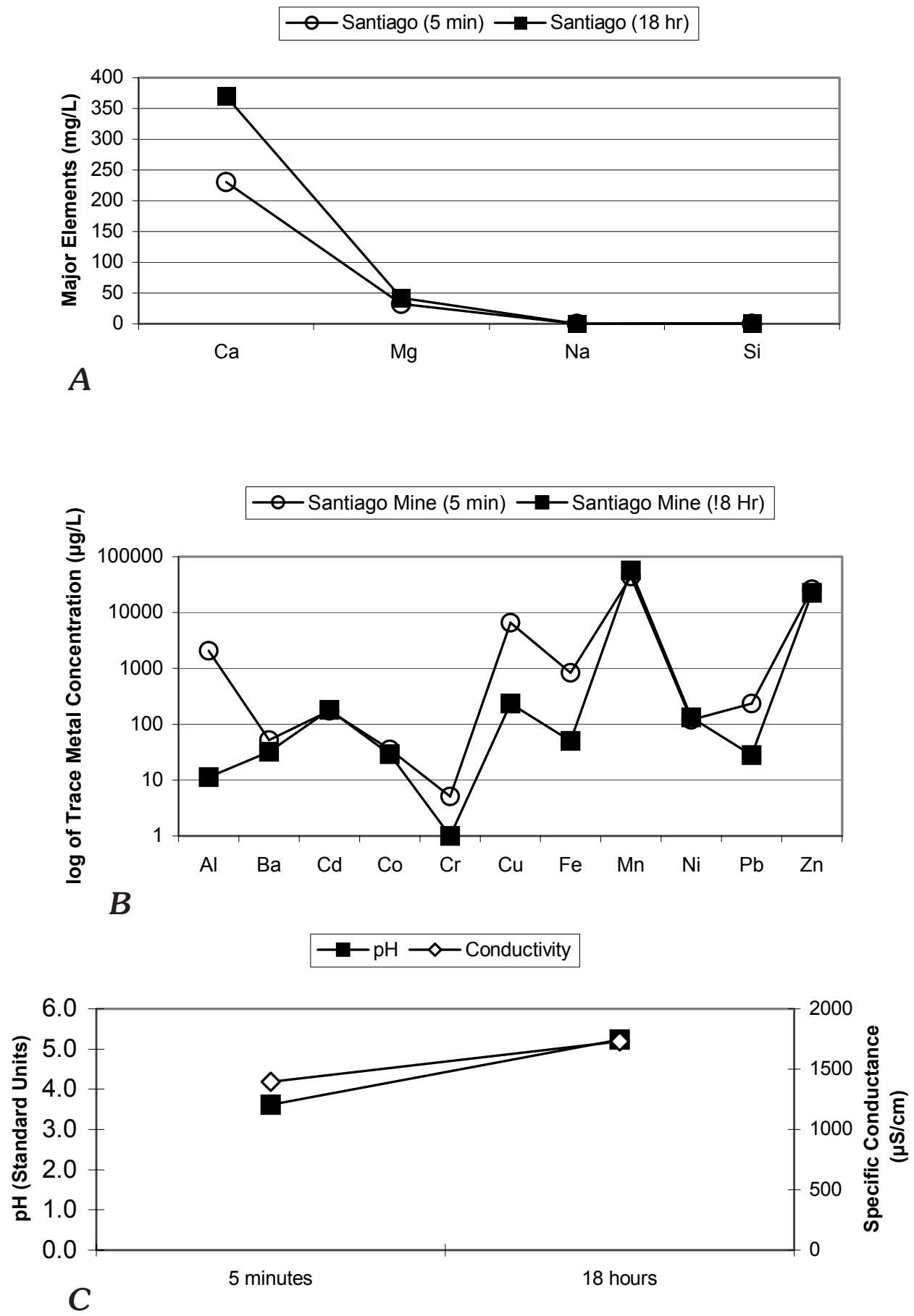

Figure 16. Santiago mine-waste leachate geochemistry trends ( 5 minutes vs. 18 hours) for $A$. selected major elements (ICP-AES); $B$, selected trace metals (ICP-MS); and $C$, pH and specific conductance. 
Using the ranking scheme in this way allows the investigator to see which mine-waste piles are potentially the worst point-source contributors and which basins have problem sites.

It should be noted that this ranking scheme only relates and pertains to the mine-waste runoff geochemistry because, once effluent from any of these sites enters a drainage system and is mixed with other waters, a multitude of changes both positive and (or) negative may occur in the water body.

Table 2 shows mine-waste rankings using short-term leaching characteristics (5-minute test). This ranking indicates which sites produce the most toxic leachate if the piles were subject to a meteorological event that produces runoff. The Santiago mine-waste is ranked first, followed by the Waldorf mine-waste. These two sites are located in the Leavenworth Creek drainage. The Togo mine-waste, located in the upper Snake River, was ranked third. It is important to note that the Santiago mine-waste also produced leachate with detectable mercury, the only site in this study to do so.

Table 3 shows mine-waste rankings using longer term leaching characteristics (18-hour test). This ranking indicates which sites produce the most toxic leachate after being agitated and leached for an extended period of time. These rankings are generally the same as those for the 5-minute leach test. Leachate from the Waldorf mine-waste was shown to have the most toxic geochemical profile according to the parameters explained above. The Togo mine-waste was second, followed by the Santiago.

Table 4 shows a ranking of the mine-wastes according to NAP results for all the mine-wastes included in this study. This ranking of results according to NAP is somewhat different than the rankings produced using leachate results. However, there also are some similarities. Four of the top five ranked using NAP are the same as for the 5-minute and 18hour leaching tests, albeit in slightly different order. The Togo mine-waste ranked first, meaning it required the most $\mathrm{CaCO}_{3}$ in order to neutralize the waste. The Santiago mine-waste was second, followed by the Lower Radical mine-waste. NAP Results for all the sites are given in the summaries for individual mine-waste sites and in Appendix 1.

\section{Conclusions}

The use of leaching tests like the 5-minute USGS field leach test are very effective in providing geochemical data to investigators. Data produced from these tests aid in predicting the geochemical characteristics of runoff from historical minewaste piles. Leachate geochemical data can be used to fingerprint individual historical mine-wastes, that is, to establish the unique leachate geochemical signature for a mine-waste pile. When used as an assessment tool on a number of mine-waste piles, geochemical fingerprints from individual mine-waste can be compared to the geochemical signature of other piles. These comparisons allow an investigator to identify the worst point-source contributors to stream-water-quality degradation. Comparison of the leachate geochemical fingerprints from the

Table 2. Mine-waste rankings for potential effects of runoff due to an event such as a thunderstorm (5-minute leach test) for 13 mine-wastes sampled.

[1, most toxic runoff geochemical characteristics; 12 , least toxic runoff geochemical characteristics for sites sampled and criteria used. Duplicate numbers in Rank column indicate a tie in mine-waste ranking

\begin{tabular}{rll}
\hline Rank & \multicolumn{1}{c}{ Mine-waste } & \multicolumn{1}{c}{ Drainage basin where mine-waste is located } \\
\hline 1 & Santiago* & Leavenworth/Clear Creek \\
2 & Waldorf & Leavenworth/Clear Creek \\
3 & Togo & Upper Snake \\
4 & Cashier & Upper Snake \\
5 & Jack Pine & Stevens Gulch/Clear Creek \\
6 & Lower Chatauqua & Deer Creek \\
7 & Arabella & Deer Creek \\
8 & Superior & Middle Snake River, below confluence with Deer Creek \\
9 & Lower Radical & Deer Creek \\
10 & Wild Irishman & Saints John Creek \\
11 & General Teller & Deer Creek \\
11 & Burke & Middle Snake River, below confluence with Deer Creek \\
12 & Grizzly & Grizzly Gulch/Clear Creek \\
\hline
\end{tabular}

*Mercury was detected in this leachate. 
Table 3. Mine-waste rankings for potential effects of runoff due to an extended leaching event (18-hour leach test) for 13 mine-wastes sampled.

[1, most toxic runoff geochemical characteristics; 12 , least toxic runoff geochemical characteristics for sites sampled and criteria used. Duplicate numbers in Rank column indicate a tie in mine-waste ranking]

\begin{tabular}{rll}
\hline Rank & \multicolumn{1}{c}{ Mine-waste } & \multicolumn{1}{c}{ Drainage basin where mine-waste is located } \\
\hline 1 & Waldorf & Leavenworth/Clear Creek \\
2 & Togo & Upper Snake \\
3 & Santiago* & Leavenworth/Clear Creek \\
4 & Jack Pine & Stevens Gulch/Clear Creek \\
5 & Cashier & Upper Snake \\
6 & Lower Chatauqua & Deer Creek \\
7 & Arabella & Deer Creek \\
8 & Lower Radical & Deer Creek \\
9 & Superior & Middle Snake below confluence with Deer Creek \\
10 & Wild Irishman & Saints John Creek \\
10 & Burke & Middle Snake below confluence with Deer Creek \\
11 & Grizzly & Grizzly Gulch/Clear Creek \\
12 & General Teller & Deer Creek \\
\hline
\end{tabular}

*Mercury was detected in this leachate.

13 mine-wastes included in this study revealed significant differences in the geochemical characteristics from mine-wastes located in adjacent basins.

I found that it is also effective to look at changes in leachate geochemistry over time. Comparison of changes in leachate geochemistry after the 5-minute leach test (simulated cloudburst) to those produced from the longer term 18-hour leach test showed that not all leachates behave in a similar manner, even though they were derived from mine-waste piles located relatively close together. Whereas comparative time trends for all 13 sites for $\mathrm{pH}$, specific conductance, and sulfate correlated well, major- and trace-element concentration changed, sometimes dramatically, as the leachate $\mathrm{pH}$ went up or down over time. Leachate time trends showed that some wastes are net acid producing, while others are net acid consuming over time. It was interesting to note that, even though $\mathrm{pH}$ went up over

Table 4. Mine-waste rankings for NAP (net-acid production).

$\left[1\right.$, requires most kilograms $\mathrm{CaCO}_{3}$ per ton in order to neutralize; 12 , requires least kilograms $\mathrm{CaCO}_{3}$ per ton in order to neutralize. Duplicate numbers in Rank column indicate a tie in mine-waste ranking]

\begin{tabular}{rll}
\hline Rank & \multicolumn{1}{c}{ Mine-waste } & \multicolumn{1}{c}{ Drainage basin where mine-waste is located } \\
\hline 1 & Togo & Upper Snake \\
2 & Santiago* & Leavenworth/Clear Creek \\
3 & Lower Radical & Deer Creek \\
4 & Waldorf & Leavenworth/Clear Creek \\
5 & Jack Pine & Stevens Gulch/Clear Creek \\
6 & Cashier & Upper Snake \\
7 & Wild Irishman & Saints John Creek \\
8 & Burke & Middle Snake Below confluence with Deer Creek \\
8 & Superior & Middle Snake Below confluence with Deer Creek \\
9 & Arabella & Deer Creek \\
10 & Lower Chatauqua & Deer Creek \\
11 & Grizzly & Grizzly Gulch \\
12 & General Teller & Deer Creek \\
\hline
\end{tabular}

\footnotetext{
*Mercurv was detected in this leachate.
} 
time in leachates from the Santiago and Waldorf mine-wastes, these two wastes produced some of the most potentially toxic leachate geochemical profiles of all the sites studied.

Finally, the use of leaching tests in conjunction with ranking protocols like those presented here is a very useful tool in showing which mine-wastes have the most potential to produce toxic runoff. Use of a consistent ranking criteria for basin-to-basin comparison can reveal which drainage basins contain mine-waste piles having the most impact on tributary river systems, as well as which individual mine-waste piles may be the greatest contributors as point-source inputs for water-quality problems. Examples of the use of relative ranking schemes given in this paper show that, according to the leachate geochemical data from the mine-wastes included in this study and the criteria used for this investigation, the minewaste piles with the most toxic geochemical profiles were produced from mines in the Leavenworth drainage basin (Waldorf and Santiago mines); whereas mine-waste piles located in the Deer Creek drainage basin generally had less potential for producing highly toxic leachates.

\section{References}

du Bray, Edward A., 1995, Preliminary compilation of descriptive geoenvironmental mineral deposit models: U.S. Geological Survey Open-File Report 95-0831, 272 p.

Fey, D.L., Church, S.E., Unruh, D.M., and Bove, D.J., 2002, Water and sediment study of the Snake River watershed, Colorado: U.S. Geological Survey Open-File Report 02-0330, 41 p.

Hageman, Philip L., 2002, Mercury in water by flow injection-cold vapor-atomic fluorescence spectrometry, chap. $N$ of Taggart, J.E., ed., Analytical methods for chemical analysis of geologic and other materials: U.S. Geological Survey Open-File Report 020223.

Hageman, Philip L., and Briggs, Paul H., 2000, A simple field leach for rapid screening and qualitative characterization of mine-waste material on abandoned mine lands, in ICARD 2000: Proceedings from the Fifth International Conference on Acid Rock Drainage, Denver, Colorado, May 21-24, 2000: Society for Mining, Metallurgy, and Exploration, Inc., p. 1463-1475.

Lapakko, K.A., and Lawrence, R.W., 1993, Modification of the netacid production (NAP) test, in Proceedings, British Columbia Mine Reclamation Symposium, Port Hardy, B.C., May 4-7, 1993, p. $145-159$.

Lovering, T.S., 1935, Geology and ore deposits of the Montezuma quadrangle, Colorado: U.S. Geological Survey Professional Paper $178,119 \mathrm{p}$.

Lamothe, P.J., Meier, A.L., and Wilson, Stephen, 1999, The determination of forty-four elements in aqueous samples by inductively coupled plasma-mass spectrometry: U.S. Geological Survey Open-File Report 99-151, 14 p.
Meier, A.L., Grimes, D.J., and Ficklin, W.H., 1994, Inductively coupled plasma-mass spectrometry: A powerful tool for mineral resource and environmental studies: U.S. Geological Survey Circular 1103-A, p. 67-68.

Munroe, E.A., 2000, Abandoned mine lands in Peru Creek, Deer Creek, upper Snake River, and Swan River watersheds: Sources of metal contamination to the environment and their amelioration through passive treatment options: [Report prepared for White River National Forest, Dillon Ranger District, Colorado].

Neuerberg, G.J., 1971, Maps showing distribution of selected accessory minerals in the Montezuma stock, Summit County, Colorado: U.S. Geological Survey Miscellaneous Geologic Investigations Map I-608, scale 1:48,000.

Neubert, J.T., Kurtz, J.P., Bove, D.J., Bird, D.A., and Sares, M.A., 2004, Natural acid rock drainage associated with hydrothermally altered terrane in Colorado: Colorado Geological Survey Bulletin $54,182 \mathrm{p}$.

Plumlee, Geoff, and Nash, J.T., 1995, Polymetallic vein and replacement deposits, in du Bray, Edward, ed., Preliminary compilation of descriptive geoenvironmental mineral deposit models: U.S. Geological Survey Open-File Report 95-0831, p. 121-129.

Smith, K.S., Ramsey, C.A., and Hageman, P.L., 2000, Sampling strategy for the rapid screening of mine-waste dumps on abandoned mine lands, in ICARD 2000: Proceedings from the Fifth International Conference on Acid Rock Drainage, Denver, Colorado, May 21-24, 2000: Society for Mining, Metallurgy, and Exploration, Inc., p. 1453-1461.

Wilson, A.B., and LaRock, E.J., 1992, Map showing mineralized areas and principal lodemines in southern Summit County, Colorado: U.S. Geological Survey Miscellaneous Field Studies Map MF-2163, scale 1:50,000.

Manuscript approvd for publication June 17, 2004

Published in the Central Region, Denver, Colorado

Editing, layout, photocomposition-Richard W. Scott, Jr. Section 508 compliance-David G. Walters

Webmaster-Tracy A. Pinto

Graphics by the author 

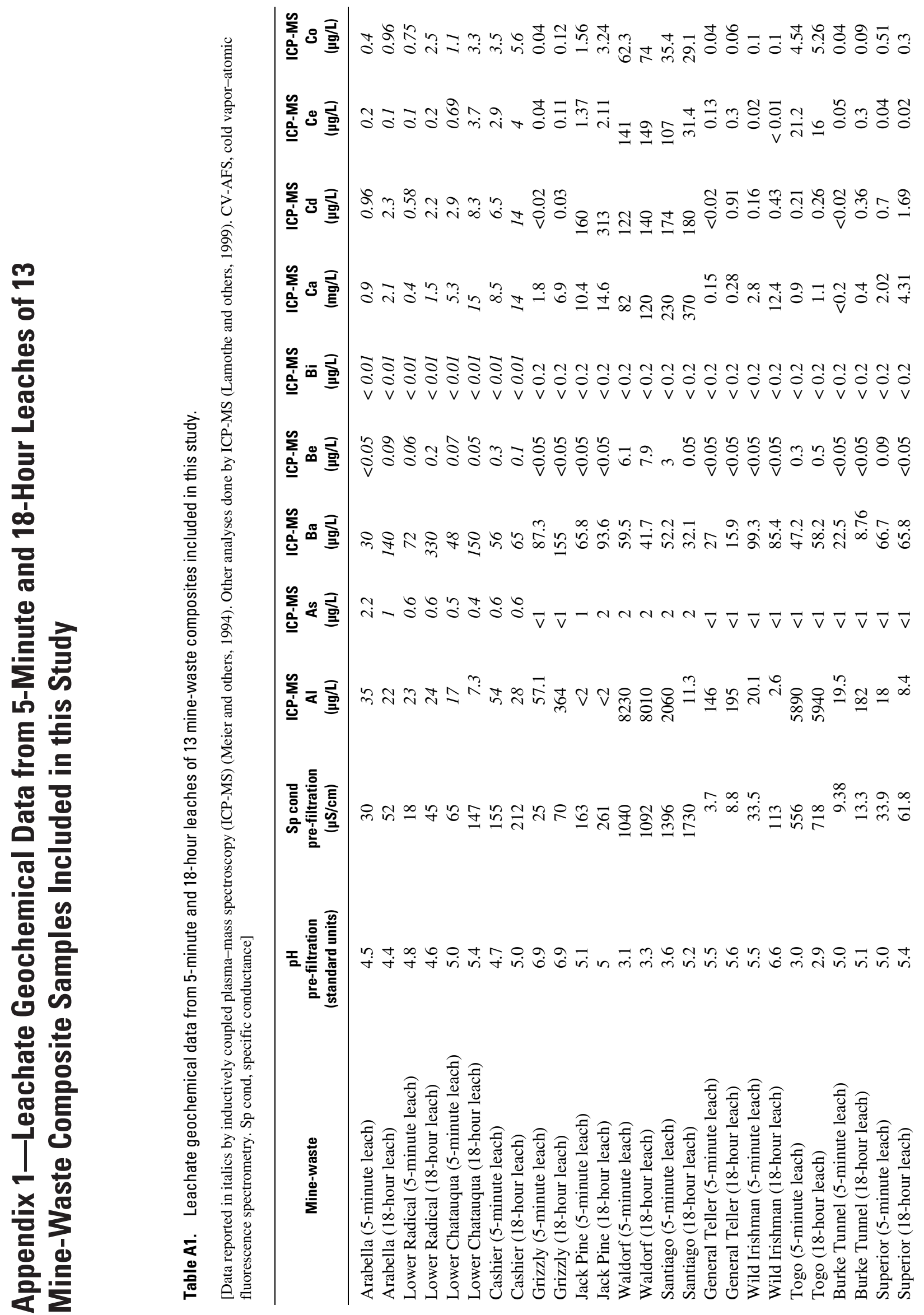


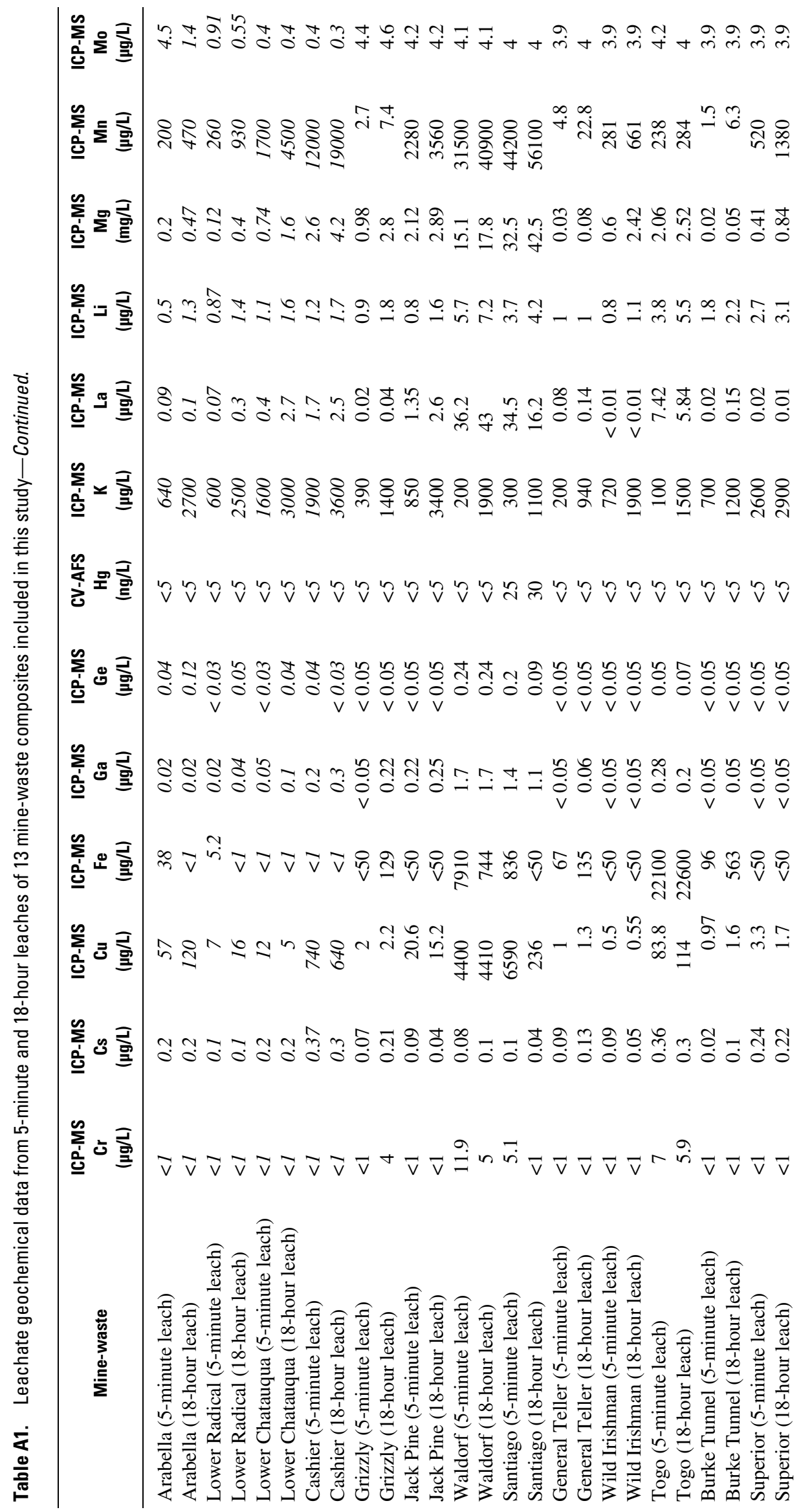




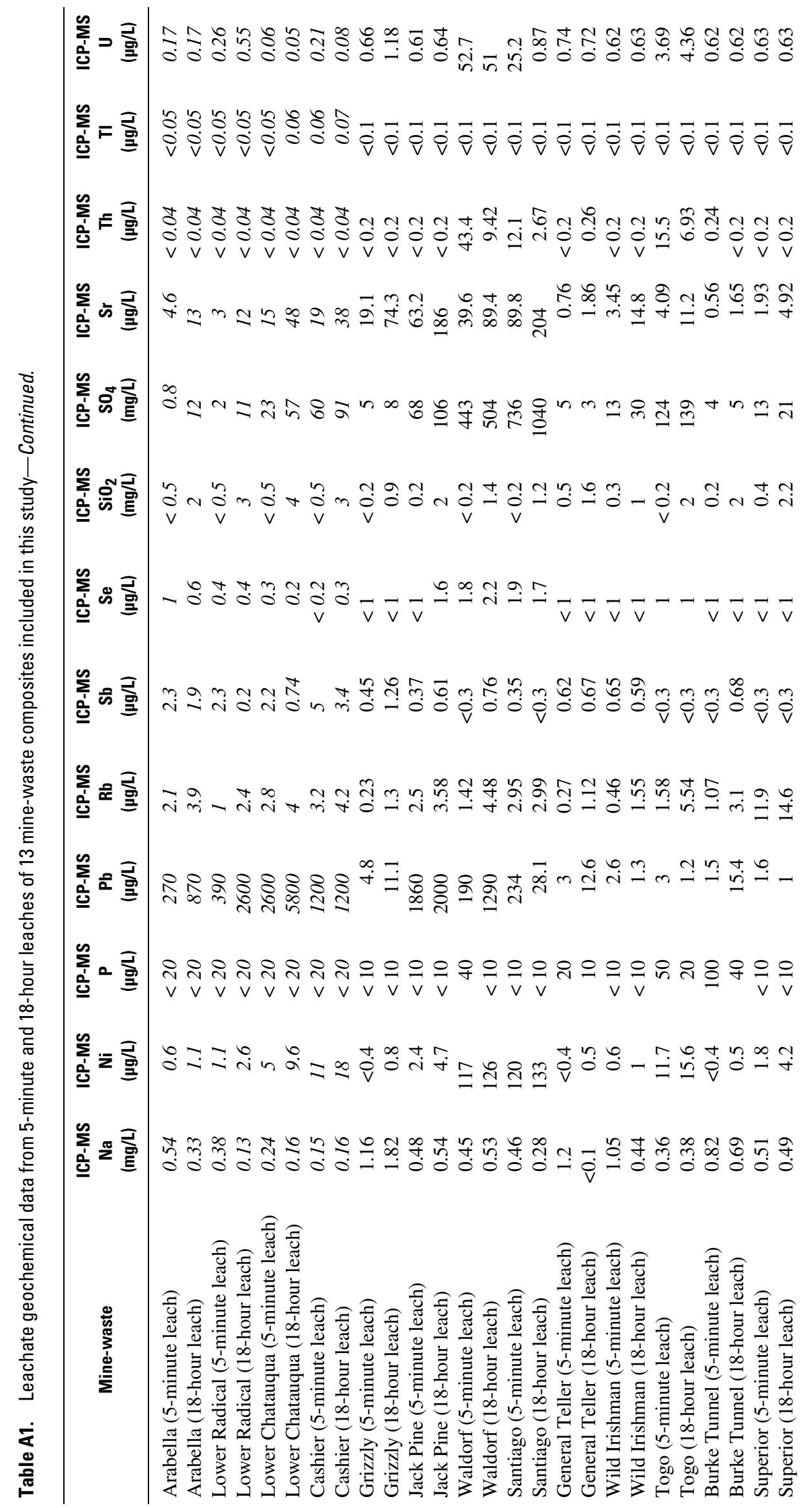


Table A1. Leachate geochemical data from 5-minute and 18-hour leaches of 13 mine-waste composites included in this study-Continued.

\begin{tabular}{|c|c|c|c|}
\hline Mine-waste & $\begin{array}{c}\text { ICP-MS } \\
\text { V } \\
(\mu \mathrm{g} / \mathrm{L})\end{array}$ & $\begin{array}{c}\text { ICP-MS } \\
Y \\
(\mu \mathrm{g} / \mathrm{L})\end{array}$ & $\begin{array}{c}\text { ICP-MS } \\
\text { Zn } \\
(\mu \mathrm{g} / \mathrm{L})\end{array}$ \\
\hline Arabella (5-minute leach) & 0.3 & 0.07 & 230 \\
\hline Arabella (18-hour leach) & $<0.1$ & 0.05 & 510 \\
\hline Lower Radical (5-minute leach) & $<0.1$ & 0.05 & 93 \\
\hline Lower Radical (18-hour leach) & $<0.1$ & 0.2 & 310 \\
\hline Lower Chatauqua (5-minute leach) & $<0.1$ & 0.3 & 460 \\
\hline Lower Chatauqua (18-hour leach) & $<0.1$ & 2.1 & 1200 \\
\hline Cashier (5-minute leach) & 0.2 & 2 & 1100 \\
\hline Cashier (18-hour leach) & 0.1 & 3.5 & 2200 \\
\hline Grizzly (5-minute leach) & $<0.5$ & $<0.01$ & 5.7 \\
\hline Grizzly (18-hour leach) & $<0.5$ & 0.02 & 9.9 \\
\hline Jack Pine (5-minute leach) & $<0.5$ & 0.22 & 19000 \\
\hline Jack Pine (18-hour leach) & $<0.5$ & 0.57 & 37700 \\
\hline Waldorf (5-minute leach) & $<0.5$ & 49.9 & 23900 \\
\hline Waldorf (18-hour leach) & $<0.5$ & 52.1 & 25500 \\
\hline Santiago (5-minute leach) & $<0.5$ & 38.1 & 26000 \\
\hline Santiago (18-hour leach) & $<0.5$ & 10 & 22600 \\
\hline General Teller (5-minute leach) & $<0.5$ & 0.06 & 5.4 \\
\hline General Teller (18-hour leach) & $<0.5$ & 0.17 & 29.8 \\
\hline Wild Irishman (5-minute leach) & $<0.5$ & $<0.01$ & 6 \\
\hline Wild Irishman (18-hour leach) & $<0.5$ & $<0.01$ & 43.8 \\
\hline Togo (5-minute leach) & $<0.5$ & 7.99 & 99.7 \\
\hline Togo (18-hour leach) & $<0.5$ & 6.81 & 112 \\
\hline Burke Tunnel (5-minute leach) & $<0.5$ & $<0.01$ & 11.3 \\
\hline Burke Tunnel (18-hour leach) & 0.6 & 0.04 & 12.6 \\
\hline Superior (5-minute leach) & $<0.5$ & 0.01 & 180 \\
\hline Superior (18-hour leach) & $<0.5$ & $<0.01$ & 387 \\
\hline
\end{tabular}

\section{Appendix 2-Net-Acid Production for 13 Mine-Waste Composite Samples Included in this Study}

Table A2. NAP (net-acid production) for 13 mine-waste composite samples included in this study.

[Results in $\mathrm{kg} \mathrm{CaCO}_{3}$ per ton]

\begin{tabular}{lr}
\hline \multicolumn{1}{c}{ Mine-waste } & NAP \\
\hline Arabella & 4.0 \\
Lower Radical & 32.0 \\
Lower Chatauqua & 3.0 \\
Cashier & 10.5 \\
Grizzly & 1.3 \\
Jack Pine & 17.5 \\
Waldorf & 24.0 \\
Santiago & 73.0 \\
General Teller & 0.5 \\
Wild Irishman & 6.5 \\
Togo & 83.0 \\
Burke Tunnel & 5.0 \\
Superior & 5.0 \\
\hline
\end{tabular}




\section{Appendix 3-Mine-Waste Geochemistry Highlights}

\section{Arabella Mine}

The Arabella mine is located in the Deer Creek drainage in the Snake River watershed. The mine is hosted in the Swandyke hornblende gneiss.

\section{Net-Acidity}

$4.0 \mathrm{~kg} \mathrm{CaCO} /$ ton.

\section{pH Trend}

There was a slight decrease in $\mathrm{pH}$ over time in the Arabella mine-waste leachate. $\mathrm{pH}$ dropped from 4.5 after 5 minutes to 4.4 after 18 hours. ( $-0.1 \mathrm{pH}$ units). This indicates minor net-acid production in the leachate over time.

\section{Specific Conductance Trend}

Leachate from the Arabella mine-waste had low specific conductance with measurements of $30 \mu \mathrm{S} / \mathrm{cm}$ after 5 minutes rising to $52 \mu \mathrm{S} / \mathrm{cm}$ after 18 hours.

\section{Sulfate}

Arabella leachate sulfate concentration was low and rose over time from $0.08 \mathrm{mg} / \mathrm{L}$ after 5 minutes to $12 \mathrm{mg} / \mathrm{L}$ after 18 hours.

\section{Selected Major-Element Trends}

The concentration of calcium in the Arabella leachate ranged from $0.9 \mathrm{mg} / \mathrm{L}$ in the 5 -minute leach to $2.1 \mathrm{mg} / \mathrm{L}$ after 18 hours.

\section{Selected Trace-Metal Trends}

Following are summaries of selected trace-element trends portrayed in the time study (5-minute vs. 18-hour) of the Arabella mine-waste leachate.

Aluminum $(A l)$.-Arabella leachate aluminum concentration decreased slightly over time. The concentration ranged from $35 \mu \mathrm{g} / \mathrm{L}$ in the 5-minute leachate and dropped to $22 \mu \mathrm{g} / \mathrm{L}$ after 18 hours. Cadmium $(\mathrm{Cd})$.- Slightly elevated concentrations of cadmium were found with concentrations of $0.96 \mu \mathrm{g} / \mathrm{L}$ after 5 minutes, rising to $2.3 \mu \mathrm{g} / \mathrm{L}$ after 18 hours.

Copper $(\mathrm{Cu})$.- Arabella leachate copper concentrations increased from $57 \mu \mathrm{g} / \mathrm{L}$ in the 5-minute leachate to $120 \mu \mathrm{g} / \mathrm{L}$ after 18 hours.

Iron $(\mathrm{Fe})$.- - The Arabella leachate iron concentration was low and a drop in iron concentration was observed over time. Iron concentration dropped from $38 \mu \mathrm{g} / \mathrm{L}$ in the 5 -minute leachate to $<1 \mu \mathrm{g} / \mathrm{L}$ after 18 hours.

Mercury $(\mathrm{Hg})$.- Mercury was not detected in the Arabella leachate.

Manganese ( $\mathrm{Mn}$ ).-Manganese was found in the leachate from the Arabella mine-waste. The 5 -minute concentration was $200 \mu \mathrm{g} / \mathrm{L}$ and rose to $470 \mu \mathrm{g} / \mathrm{L}$ after 18 hours.

Nickel ( $\mathrm{Ni}$ ).-Minor concentrations of nickel were found in the leachate with slight increase in leachate concentration over time. 5-minute concentration was $0.6 \mu \mathrm{g} / \mathrm{L}$; this value rose to $1.1 \mu \mathrm{g} / \mathrm{L}$ after 18 hours.

Lead $(\mathrm{Pb})$.- - There were elevated lead concentrations in the Arabella leachate. Also, leachate lead concentration rose over time from $270 \mu \mathrm{g} / \mathrm{L}$ after 5 minutes to $870 \mu \mathrm{g} / \mathrm{L}$ after 18 hours.

Zinc (Zn).--Very high concentrations of zinc were found in the Arabella leachate, and zinc concentrations rose over time. The 5-minute concentration was $230 \mu \mathrm{g} / \mathrm{L}$; this value rose to $510 \mu \mathrm{g} / \mathrm{L}$ after 18 hours.

\section{Lower Radical Mine}

The Lower Radical mine is located in the Deer Creek drainage in the Snake River watershed. The mine is hosted in the Swandyke hornblende gneiss.

\section{Net-Acidity}

$32 \mathrm{~kg} \mathrm{CaCO}_{3} /$ ton.

\section{pH Trend}

There was a slight decrease in $\mathrm{pH}$ over time in the Lower Radical mine-waste leachate. $\mathrm{pH}$ dropped from 4.8 after 5 minutes to 4.6 after 18 hours. ( $-0.2 \mathrm{pH}$ units). This indicates slight net-acid production in the leachate over time. 


\section{Specific Conductance Trend}

Leachate from the Lower Radical mine-waste had low specific conductance with measurements of $18 \mu \mathrm{S} / \mathrm{cm}$ after 5 minutes, rising to $45 \mu \mathrm{S} / \mathrm{cm}$ after 18 hours.

\section{Sulfate}

Lower Radical leachate sulfate concentrations were low and rose over time from $2.0 \mathrm{mg} / \mathrm{L}$ after 5 minutes to $11 \mathrm{mg} / \mathrm{L}$ after 18 hours.

\section{Selected Major-Element Trends}

Lower Radical leachate had minor concentration of calcium, ranging from $0.4 \mathrm{mg} / \mathrm{L}$ in the 5-minute leach to 1.5 $\mathrm{mg} / \mathrm{L}$ after 18 hours.

\section{Selected Trace-Metal Trends}

Following are summaries of selected trace-element trends portrayed in the time study (5-minute vs. 18-hour) of the Lower Radical mine-waste leachate.

Aluminum ( $A l)$.- - Lower Radical leachate had low concentrations of aluminum, and the concentration remained almost constant over time. Concentration ranged from $23 \mu \mathrm{g} / \mathrm{L}$ in the 5-minute leachate to 24 $\mu \mathrm{g} / \mathrm{L}$ after 18 hours.

Cadmium $(\mathrm{Cd})$.- Minor concentrations of cadmium were found. Values ranged from $0.58 \mu \mathrm{g} / \mathrm{L}$ after 5 minutes, rising to $2.2 \mu \mathrm{g} / \mathrm{L}$ after 18 hours. Copper $(\mathrm{Cu})$.- - Lower Radical leachate copper concentrations were minor. Values were $7 \mu \mathrm{g} / \mathrm{L}$ in the 5-minute leachate and $16 \mu \mathrm{g} / \mathrm{L}$ after 18 hours. Iron $(\mathrm{Fe})$.- - Lower Radical leachate iron concentrations were low and dropped over time from 5.2 $\mu \mathrm{g} / \mathrm{L}$ in the 5-minute leachate $<1 \mu \mathrm{g} / \mathrm{L}$ after 18 hours.

Manganese ( $\mathrm{Mn})$.- - Manganese was found in the leachate from the Lower Radical mine-waste. The 5 -minute concentration was $260 \mu \mathrm{g} / \mathrm{L}$ and rose to 930 after 18 hours.

Mercury $(\mathrm{Hg})$.- Mercury was not detected in the Lower Radical leachate.

Nickel (Ni).-Minor concentrations of nickel were found in the leachate with a slight increase in leachate concentration over time. The 5-minute concentration was $1.1 \mu \mathrm{g} / \mathrm{L}$; this value rose to 2.6 $\mu \mathrm{g} / \mathrm{L}$ after 18 hours.

Lead $(\mathrm{Pb})$.- There was elevated lead in the leachate and concentration increased over time from 390 $\mu \mathrm{g} / \mathrm{L}$ after 5 minutes to $2,600 \mu \mathrm{g} / \mathrm{L}$ after 18 hours. Zinc $(\mathrm{Zn})$._-Zinc was found in the Lower Radical leachate, and zinc concentrations rose over time. 5-minute concentration was $93 \mu \mathrm{g} / \mathrm{L}$; this value rose to 310 after 18 hours.

\section{Lower Chatauqua Mine}

The Lower Chatauqua mine is located in the Deer Creek drainage in the Snake River watershed. The mine is hosted in the Swandyke hornblende gneiss and schist with galena in branching veins or breccias cemented by Manganese-rich ankerite and quartz.

Net-Acidity

$3.0 \mathrm{~kg} \mathrm{CaCO} /$ ton.

$\mathrm{pH}$ Trend

There was an increase in $\mathrm{pH}$ over time in the Lower Chatauqua mine-waste leachate. $\mathrm{pH}$ rose from 5.0 after 5 minutes to 5.4 after 18 hours. (+0.4 pH units). This indicates netacid neutralization of the leachate over time.

\section{Specific Conductance Trend}

Leachate from the Lower Chatauqua mine-waste had low specific conductance with measurements of $65 \mu \mathrm{S} / \mathrm{cm}$ after 5 minutes, rising to $147 \mu \mathrm{S} / \mathrm{cm}$ after 18 hours.

\section{Sulfate}

Sulfate concentrations were low and rose over time from $23 \mathrm{mg} / \mathrm{L}$ after 5 minutes to $57 \mathrm{mg} / \mathrm{L}$ after 18 hours.

\section{Selected Major-Element Trends}

Lower Chatauqua leachate had calcium that ranged from $5.3 \mathrm{mg} / \mathrm{L}$ in the 5 -minute leach to $15 \mathrm{mg} / \mathrm{L}$ after 18 hours.

\section{Selected Trace-Metal Trends}

Following are summaries of selected trace-element trends portrayed in the time study (5-minute vs. 18-hour) of the Lower Chatauqua mine-waste leachates.

Aluminum $(A l)$. - Lower Chatauqua leachate had minor aluminum concentration. The aluminum concentration went down over time. Concentration ranged from $17 \mu \mathrm{g} / \mathrm{L}$ in the 5-minute leachate and decreased to $7.3 \mu \mathrm{g} / \mathrm{L}$ after 18 hours. 
Cadmium $(C d)$.- - Minor concentration of cadmium was found with concentrations of $2.9 \mu \mathrm{g} / \mathrm{L}$ after 5 minutes, rising to $8.3 \mu \mathrm{g} / \mathrm{L}$ after 18 hours.

Copper $(\mathrm{Cu})$.- Minor leachate copper concentration was found, and concentration went down over time. Values ranged from $12 \mu \mathrm{g} / \mathrm{L}$ in the 5 -minute leachate to $5 \mu \mathrm{g} / \mathrm{L}$ after 18 hours.

Iron $(\mathrm{Fe})$.- - Iron was not detected at instrument detection limits. Both 5-minute and 18-hour leachates had iron concentrations of $<1 \mu \mathrm{g} / \mathrm{L}$.

Manganese ( $\mathrm{Mn})$.--Moderately high concentration of manganese was found in the leachate.

The 5-minute concentration was $1,700 \mu \mathrm{g} / \mathrm{L}$ and increased to $4,500 \mu \mathrm{g} / \mathrm{L}$ after 18 hours.

Mercury $(\mathrm{Hg})$.- Mercury was not detected in the Lower Chatauqua mine-waste leachate.

Nickel ( $\mathrm{Ni}$ ).--Minor concentration of nickel was found with an increase in leachate concentration over time. The 5 -minute concentration was $5 \mu \mathrm{g} / \mathrm{L}$ and rose to $9.6 \mu \mathrm{g} / \mathrm{L}$ after 18 hours.

Lead $(\mathrm{Pb})$.- - High leachate lead concentration was found and lead concentration rose over time from $2,600 \mu \mathrm{g} / \mathrm{L}$ after 5 minutes to $5,800 \mu \mathrm{g} / \mathrm{L}$ after 18 hours.

Zinc (Zn).--Moderately elevated concentrations of zinc were found in the Lower Chatauqua leachate, and zinc concentrations rose over time. The 5 -minute concentration was $460 \mu \mathrm{g} / \mathrm{L}$; this value dropped to $1,200 \mu \mathrm{g} / \mathrm{L}$ after 18 hours

\section{General Teller Mine}

The General Teller mine is located in the Deer Creek drainage in the Snake River watershed. The mine is hosted in Swandyke hornblende gneiss with pegmatite intrusions.

\section{Net-Acidity}

$0.5 \mathrm{~kg} \mathrm{CaCO} /$ ton.

\section{pH Trend}

There was a slight increase in $\mathrm{pH}$ over time in the General Teller mine-waste leachate. $\mathrm{pH}$ rose from 5.5 after 5 minutes to 5.6 after 18 hours. (+0.1 pH units). This indicates net-acid neutralization of the leachate over time.

\section{Specific Conductance Trend}

Leachate from the General Teller mine-waste had low specific conductance with measurements of $3.7 \mu \mathrm{S} / \mathrm{cm}$ after 5 minutes, rising to $8.8 \mu \mathrm{S} / \mathrm{cm}$ after 18 hours.

\section{Sulfate}

General Teller leachate sulfate concentration was low and decreased over time from $5 \mathrm{mg} / \mathrm{L}$ after 5 minutes to $3 \mathrm{mg} / \mathrm{L}$ after 18 hours.

\section{Selected Major-Element Trends}

General Teller leachate had very minor concentration of calcium that ranged from $0.15 \mathrm{mg} / \mathrm{L}$ in the 5 -minute leach to $0.28 \mathrm{mg} / \mathrm{L}$ after 18 hours. Interestingly, sodium concentration dropped over time from $1.2 \mathrm{mg} / \mathrm{L}$ after 5 minutes to $<0.1 \mathrm{mg} / \mathrm{L}$ after 18 hours.

\section{Selected Trace-Metal Trends}

Following are summaries of selected trace-element trends portrayed in the time study (5-minute vs. 18-hour) of the General Teller mine-waste leachate.

Aluminum (Al).-General Teller leachate had low concentrations of aluminum. Concentrations ranged from $146 \mu \mathrm{g} / \mathrm{L}$ in the 5-minute leachate and rose to $195 \mu \mathrm{g} / \mathrm{L}$ after 18 hours.

Cadmium $(\mathrm{Cd})$.- - Low concentrations of cadmium were found with concentrations of $<0.02 \mu \mathrm{g} / \mathrm{L}$ after 5 minutes, rising to $0.91 \mu \mathrm{g} / \mathrm{L}$ after 18 hours.

Copper $(\mathrm{Cu})$.- - General Teller leachate had low copper concentrations and ranged from $1.0 \mu \mathrm{g} / \mathrm{L}$ in the 5-minute leachate to $1.3 \mu \mathrm{g} / \mathrm{L}$ after 18 hours.

Iron $(\mathrm{Fe})$.- - General Teller leachate iron concentrations were low. Iron concentrations ranged from 67 $\mu \mathrm{g} / \mathrm{L}$ in the 5-minute leachate and rose to $135 \mu \mathrm{g} / \mathrm{L}$ after 18 hours.

Manganese (Mn).-Low concentrations of manganese were found in leachate from the General Teller mine-waste. Manganese values ranged from $4.8 \mu \mathrm{g} / \mathrm{L}$ to 22.8 after 18 hours.

Mercury $(\mathrm{Hg})$.- Mercury was not detected in the General Teller leachate.

Nickel (Ni).-Minor concentrations of nickel were found in the leachate with a very slight increase in leachate concentration over time. The 5-minute concentration was $<0.4 \mu \mathrm{g} / \mathrm{L}$, rising to $0.5 \mu \mathrm{g} / \mathrm{L}$ after 18 hours.

Lead $(\mathrm{Pb})$.- - Leachate lead concentration was minor and rose over time from $3 \mu \mathrm{g} / \mathrm{L}$ after 5 minutes to $12.6 \mu \mathrm{g} / \mathrm{L}$ after 18 hours.

Zinc $(\mathrm{Zn})$.--Minor concentrations of zinc were found in the General Teller leachate and the concentration rose over time. The 5-minute zinc concentration was $5.4 \mu \mathrm{g} / \mathrm{L}$; this value rose to 29.8 $\mu \mathrm{g} / \mathrm{L}$ after 18 hours. 


\section{Cashier Mine}

The Cashier mine is located in the very upper reach of the Snake River. The mine is hosted in Swandyke hornblende gneiss, with barite gangue, and no ankerite.

\section{Net-Acidity}

$10.5 \mathrm{~kg} \mathrm{CaCO}_{3} /$ ton.

\section{pH Trend}

There was an increase in $\mathrm{pH}$ over time in the Cashier mine-waste leachate. $\mathrm{pH}$ rose from 4.7 after 5 minutes to 5.0 after 18 hours. ( $+0.3 \mathrm{pH}$ units). This indicates net-acid neutralization in the leachate over time.

\section{Specific Conductance Trend}

Leachate from the Cashier mine-waste had low specific conductance with measurements of $155 \mu \mathrm{S} / \mathrm{cm}$ after 5 minutes, rising to $212 \mu \mathrm{S} / \mathrm{cm}$ after 18 hours.

\section{Sulfate}

Cashier leachate sulfate concentration was low and went up over time from $60 \mathrm{mg} / \mathrm{L}$ after 5 minutes to $91 \mathrm{mg} / \mathrm{L}$ after 18 hours.

\section{Selected Major-Element Trends}

The leachate had minor concentration of calcium that ranged from $8.5 \mathrm{mg} / \mathrm{L}$ in the 5 -minute leach to $14 \mathrm{mg} / \mathrm{L}$ after 18 hours.

\section{Selected Trace-Metal Trends}

Following are summaries of selected trace-element trends portrayed in the time study (5-minute vs. 18-hour) of the Cashier mine-waste leachate.

Aluminum ( $\mathrm{Al}$ ).-Cashier leachate had low concentrations of aluminum. Concentration ranged from $54 \mu \mathrm{g} / \mathrm{L}$ in the 5-minute leachate and decreased to $28 \mu \mathrm{g} / \mathrm{L}$ after 18 hours.

Cadmium $(C d)$. - Low concentrations of cadmium were found, with concentrations of $6.5 \mu \mathrm{g} / \mathrm{L}$ after 5 minutes, rising to $14 \mu \mathrm{g} / \mathrm{L}$ after 18 hours.

Copper $(\mathrm{Cu})$.-Copper concentration was moderately high and decreased over time from $740 \mu \mathrm{g} / \mathrm{L}$ in the 5-minute leachate to $640 \mu \mathrm{g} / \mathrm{L}$ after 18 hours.
Iron $(\mathrm{Fe})$.- No iron was found at instrument detection limits in the leachate from the Cashier minewaste. Both the 5-minute and 18-hour leachate concentration were $<1 \mu \mathrm{g} / \mathrm{L}$.

Manganese (Mn).--Very high concentration of manganese was found. Manganese values ranged from $12,000 \mu \mathrm{g} / \mathrm{L}$ in the 5 -minute leachate to 19,000 after 18 hours.

Mercury $(\mathrm{Hg})$.- Mercury was not detected in the Cashier leachate.

Nickel (Ni).-Minor concentrations of nickel were found in the leachate with an increase in leachate concentration over time. The 5-minute concentration was $11 \mu \mathrm{g} / \mathrm{L}$, rising to $18 \mu \mathrm{g} / \mathrm{L}$ after 18 hours. Lead $(\mathrm{Pb})$.- - Leachate lead concentration was elevated and did not change over time staying at 1,200 $\mu \mathrm{g} / \mathrm{L}$ in both the 5-minute and 18-hour tests.

Zinc $(\mathrm{Zn})$.- - High concentrations of zinc were found in the Cashier leachate and the concentration rose over time. The 5-minute zinc concentration was $1,100 \mu \mathrm{g} / \mathrm{L}$; this value rose to $2,200 \mu \mathrm{g} / \mathrm{L}$ after 18 hours.

\section{Togo Mine}

The Togo mine is located in the upper reach of the Snake River prior to confluence with Deer Creek. The mine is hosted in the Idaho Springs formation.

\section{Net-Acidity}

$83 \mathrm{~kg} \mathrm{CaCO}_{3} / \mathrm{ton}$.

\section{pH Trend}

There was a slight decrease in $\mathrm{pH}$ over time in the Togo mine-waste leachate. $\mathrm{pH}$ went down from 3.0 after 5 minutes to 2.9 after 18 hours. ( $-0.1 \mathrm{pH}$ units). This indicates net-acid production the leachate over time.

\section{Specific Conductance Trend}

Leachate from the Togo mine-waste had moderate conductance with measurements of $556 \mu \mathrm{S} / \mathrm{cm}$ after 5 minutes, rising to $718 \mu \mathrm{S} / \mathrm{cm}$ after 18 hours.

\section{Sulfate}

Togo leachate sulfate concentration went up over time from $124 \mathrm{mg} / \mathrm{L}$ after 5 minutes to $139 \mathrm{mg} / \mathrm{L}$ after 18 hours. 


\section{Selected Major-Element Trends}

Togo leachate had minor concentration of calcium that ranged from $0.9 \mathrm{mg} / \mathrm{L}$ in the 5 -minute leach to $1.1 \mathrm{mg} / \mathrm{L}$ after 18 hours.

\section{Selected Trace-Metal Trends}

Following are summaries of selected trace-element trends portrayed in the time study (5-minute vs. 18-hour) of the Togo mine-waste leachate.

Aluminum (Al).- - Togo leachate had high concentrations of aluminum. Concentration ranged from $5,890 \mu \mathrm{g} / \mathrm{L}$ in the 5 -minute leachate and rose to $5,940 \mu \mathrm{g} / \mathrm{L}$ after 18 hours.

Cadmium $(C d)$.- - Low concentrations of cadmium were found with concentrations of $0.21 \mu \mathrm{g} / \mathrm{L}$ after 5 minutes, rising to $0.26 \mu \mathrm{g} / \mathrm{L}$ after 18 hours. Copper $(\mathrm{Cu})$.- - Togo leachate copper concentrations ranged from $83.8 \mu \mathrm{g} / \mathrm{L}$ in the 5-minute leachate to $114 \mu \mathrm{g} / \mathrm{L}$ after 18 hours.

Iron $(\mathrm{Fe})$.- - Togo leachate iron concentrations were the highest of all 13 sites studied. Iron concentration ranged from $22,100 \mu \mathrm{g} / \mathrm{L}$ in the 5 -minute leachate and rose to $22,600 \mu \mathrm{g} / \mathrm{L}$ after 18 hours. Manganese (Mn).--Somewhat high concentrations of manganese were found in leachate from the Togo mine-waste. Manganese values ranged from $238 \mu \mathrm{g} / \mathrm{L}$ in the 5 -minute leachate to 284 after 18 hours.

Mercury $(\mathrm{Hg})$.--Mercury was not detected in the Togo leachate.

Nickel $(\mathrm{Ni})$.- - Minor concentrations of nickel were found in the leachate with a minor increase in leachate concentration over time. The 5-minute concentration was $11.7 \mu \mathrm{g} / \mathrm{L}$, rising to $15.6 \mu \mathrm{g} / \mathrm{L}$ after 18 hours.

Lead $(\mathrm{Pb})$.- - Leachate lead concentration was minor and decreased over time from $3 \mu \mathrm{g} / \mathrm{L}$ after 5 minutes to $1.2 \mu \mathrm{g} / \mathrm{L}$ after 18 hours.

Zinc $(\mathrm{Zn})$.-Moderate concentrations of zinc were found in the Togo leachate and the concentration rose over time. The 5-minute zinc concentration was $99.7 \mu \mathrm{g} / \mathrm{L}$; this value rose to $112 \mu \mathrm{g} / \mathrm{L}$ after 18 hours.

\section{Burke Mine}

The Burke mine is located in the Snake River watershed below the confluence with Deer Creek. The mine is hosted in the Swandyke hornblende gneiss.

\section{Net-Acidity}

$$
5.0 \mathrm{~kg} \mathrm{CaCO} / \text { ton. }
$$

pH Trend

There was a slight increase in $\mathrm{pH}$ over time in the Burke mine-waste leachate. $\mathrm{pH}$ rose from 5.0 after 5 minutes to 5.1 after 18 hours. (+0.1 pH units). This indicates net-acid production in the leachate over time.

\section{Specific Conductance Trend}

The Burke leachate had the second lowest conductance of the 13 sites studied, with measurements of $9.38 \mu \mathrm{S} / \mathrm{cm}$ after 5 minutes, rising to $13.3 \mu \mathrm{S} / \mathrm{cm}$ after 18 hours.

\section{Sulfate}

The sulfate concentration was very low with concentrations of $4 \mathrm{mg} / \mathrm{L}$ after 5 minutes and $5 \mathrm{mg} / \mathrm{L}$ after 18 hours.

\section{Selected Major-Element Trends}

Burke leachate had very low calcium concentration that ranged from $<0.2 \mathrm{mg} / \mathrm{L}$ in the 5 -minute leach to $0.4 \mathrm{mg} / \mathrm{L}$ after 18 hours.

\section{Selected Trace-Metal Trends}

Following are summaries of selected trace-element trends portrayed in the time study (5-minute vs. 18-hour) of the Burke mine-waste leachate.

Aluminum ( $A l)$.- This leachate had aluminum concentration that ranged from $19.5 \mu \mathrm{g} / \mathrm{L}$ in the 5 minute leachate and increased to $182 \mu \mathrm{g} / \mathrm{L}$ after 18 hours.

Cadmium $(\mathrm{Cd})$.--Minor concentration of cadmium was found in the Burke mine-waste leachate with values of $<0.02 \mu \mathrm{g} / \mathrm{L}$ after 5 minutes, rising to 0.38 $\mu \mathrm{g} / \mathrm{L}$ after 18 hours.

Copper $(\mathrm{Cu})$.- Minor leachate copper concentration was found and the concentration rose over time. Values ranged from $0.97 \mu \mathrm{g} / \mathrm{L}$ in the 5-minute leachate to $1.6 \mu \mathrm{g} / \mathrm{L}$ after 18 hours.

Iron $(\mathrm{Fe})$.- - Iron was found in moderate concentration in leachate from the Burke mine-waste. Leachate concentration increased over time from $96 \mu \mathrm{g} / \mathrm{L}$ in the 5 -minute leachate to $563 \mu \mathrm{g} / \mathrm{L}$ after 18 hours. Manganese (Mn).-Low concentration of manganese was found in the leachate. 5-minute leachate concentration was $1.5 \mu \mathrm{g} / \mathrm{L}$ and increased to 6.3 $\mu \mathrm{g} / \mathrm{L}$ after 18 hours.

Mercury $(\mathrm{Hg})$.- Mercury was not detected in the Burke leachate.

Nickel $(\mathrm{Ni})$._-Very minor concentration of nickel 
was found. The 5-minute leachate concentration was $<0.4 \mu \mathrm{g} / \mathrm{L}$, increasing to $0.5 \mu \mathrm{g} / \mathrm{L}$ after 18 hours.

Lead $(P b)$. - Low leachate lead concentration was found and concentration increased over time from $1.5 \mu \mathrm{g} / \mathrm{L}$ after 5 minutes to $15.4 \mu \mathrm{g} / \mathrm{L}$ after 18 hours.

Zinc $(\mathrm{Zn})$.--Minor concentration of zinc was found in the Burke leachate, and zinc concentration increased over time. The 5-minute leachate concentration was $11.3 \mu \mathrm{g} / \mathrm{L}$; this value rose slightly to $12.6 \mu \mathrm{g} / \mathrm{L}$ after 18 hours.

\section{Jack Pine Mine}

The Jack Pine mine is located in Stevens Gulch in the Clear Creek watershed. The mine is hosted in the Idaho Springs Formation.

\section{Net-Acidity}

\section{$17.5 \mathrm{~kg} \mathrm{CaCO}_{3} /$ ton.}

\section{$\mathrm{pH}$ Trend}

There was a slight decrease in $\mathrm{pH}$ over time in the Jack Pine mine-waste leachate. $\mathrm{pH}$ dropped from 5.1 after $5 \mathrm{~min}$ utes to 5.0 after 18 hours. ( $-0.1 \mathrm{pH}$ units). This indicates netacid production in the leachate over time.

\section{Specific Conductance Trend}

Jack Pine leachate had low specific conductance with measurements of $163 \mu \mathrm{S} / \mathrm{cm}$ after 5 minutes, rising to 261 $\mu \mathrm{S} / \mathrm{cm}$ after 18 hours.

\section{Sulfate}

Sulfate concentration was low with concentrations of 68 $\mathrm{mg} / \mathrm{L}$ after 5 minutes and $106 \mathrm{mg} / \mathrm{L}$ after 18 hours.

\section{Selected Major-Element Trends}

Jack Pine leachate had moderately low calcium concentration that ranged from $10.4 \mathrm{mg} / \mathrm{L}$ in the 5 -minute leach to 14.6. $\mathrm{mg} / \mathrm{L}$ after 18 hours.

\section{Selected Trace-Metal Trends}

Following are summaries of selected trace-element trends portrayed in the time study (5-minute vs. 18-hour) of the Jack Pine mine-waste leachate.
Aluminum ( $A l)$.-No aluminum was found in the leachate. Both the 5-minute and 18 -hour values were $<2 \mu \mathrm{g} / \mathrm{L}$.

Cadmium $(C d)$. - Elevated concentration of cadmium was found in the leachate with values of 160 $\mu \mathrm{g} / \mathrm{L}$ after 5 minutes, increasing to $313 \mu \mathrm{g} / \mathrm{L}$ after 18 hours.

Copper $(\mathrm{Cu})$.- Moderate leachate copper concentration was found and the concentration decreased slightly over time. Values ranged from $20.6 \mu \mathrm{g} / \mathrm{L}$ in the 5-minute leachate to $15.2 \mu \mathrm{g} / \mathrm{L}$ after 18 hours.

Iron $(\mathrm{Fe})$.- - No iron was found in the Jack Pine leachate at the ICP-MS detection limit. Both the 5minute and 18-hour leachates were $<50 \mu \mathrm{g} / \mathrm{L}$.

Manganese $(\mathrm{Mn})$.- -Elevated manganese was found in the Jack Pine leachate. The 5-minute concentration was $2,280 \mu \mathrm{g} / \mathrm{L}$, increasing to $3,560 \mu \mathrm{g} / \mathrm{L}$ after 18 hours.

$\operatorname{Mercury}(\mathrm{Hg})$.- Mercury was not detected in the Jack Pine leachate.

Nickel (Ni).- -Nickel was found in the leachate with a 5-minute concentration of $2.4 \mu \mathrm{g} / \mathrm{L}$, increasing to $4.7 \mu \mathrm{g} / \mathrm{L}$ after 18 hours.

Lead $(\mathrm{Pb})$.- - High leachate concentration of leachate lead was found, and lead concentration increased over time from $1,860 \mu \mathrm{g} / \mathrm{L}$ after $5 \mathrm{~min}$ utes to $2,000 \mu \mathrm{g} / \mathrm{L}$ after 18 hours.

Zinc (Zn).--Very high concentration of zinc was found in the Jack Pine leachate, and zinc concentration increased over time. The 5-minute concentration was $19,000 \mu \mathrm{g} / \mathrm{L}$; this value increased to $37,700 \mu \mathrm{g} / \mathrm{L}$ after 18 hours. This is one of the highest concentrations of zinc found in the 13 minewaste sites included in this study. .

\section{Superior Mine}

The Superior mine is located in the Snake River drainage just below the confluence with Deer Creek. The mine is hosted in the Swandyke hornblende gneiss.

\section{Net-Acidity}

$5.0 \mathrm{~kg} \mathrm{CaCO}_{3} /$ ton.

\section{pH Trend}

There was an increase in $\mathrm{pH}$ over time in the Superior mine-waste leachate. $\mathrm{pH}$ rose from 5.0 after 5 minutes to 5.4 after 18 hours. ( $+0.4 \mathrm{pH}$ units). This indicates net-acid neutralization of the leachate over time. 


\section{Specific Conductance Trend}

Superior leachate had low specific conductance with measurements of $33.9 \mu \mathrm{S} / \mathrm{cm}$ after 5 minutes, rising to 61.8 $\mu \mathrm{S} / \mathrm{cm}$ after 18 hours.

\section{Sulfate}

Sulfate concentration was low in the leachate with concentrations of $13 \mathrm{mg} / \mathrm{L}$ after 5 minutes and $21 \mathrm{mg} / \mathrm{L}$ after 18 hours.

\section{Selected Major-Element Trends}

Superior leachate had low calcium concentration that ranged from $2.02 \mathrm{mg} / \mathrm{L}$ in the 5 -minute leach to $4.31 \mathrm{mg} / \mathrm{L}$ after 18 hours.

\section{Selected Trace-Metal Trends}

Following are summaries of selected trace-element trends portrayed in the time study (5-minute vs. 18-hour) of the Superior mine-waste leachate.

Aluminum ( $\mathrm{Al}$ ).-This leachate had aluminum concentration that ranged from $18 \mu \mathrm{g} / \mathrm{L}$ in the 5 -minute leachate and decreased to $8.4 \mu \mathrm{g} / \mathrm{L}$ after 18 hours.

Cadmium $(\mathrm{Cd})$.- -Minor concentration of cadmium was found in the Superior mine-waste leachate with values of $0.7 \mu \mathrm{g} / \mathrm{L}$ after 5 minutes, rising to $1.69 \mu \mathrm{g} / \mathrm{L}$ after 18 hours.

Copper $(\mathrm{Cu})$.- Minor leachate copper concentration was found and the concentration decreased slightly over time. Values ranged from $0.24 \mu \mathrm{g} / \mathrm{L}$ in the 5-minute leachate to $0.22 \mu \mathrm{g} / \mathrm{L}$ after 18 hours.

Iron $(\mathrm{Fe})$.- - Iron was found in low concentration in the leachate, and concentration decreased over time from $3.3 \mu \mathrm{g} / \mathrm{L}$ in the 5-minute to $1.7 \mu \mathrm{g} / \mathrm{L}$ after 18 hours.

Manganese (Mn).-Moderate concentration of manganese was found in the Superior leachate. The 5 -minute concentration was $520 \mu \mathrm{g} / \mathrm{L}$ and increased to $1,380 \mu \mathrm{g} / \mathrm{L}$ after 18 hours.

Mercury $(\mathrm{Hg})$.- Mercury was not detected in the Superior leachate.

Nickel (Ni).-Nickel was found in the leachate, with a 5-minute concentration of $1.8 \mu \mathrm{g} / \mathrm{L}$, increasing to $4.2 \mu \mathrm{g} / \mathrm{L}$ after 18 hours.

Lead $(\mathrm{Pb})$.- - Low leachate lead concentration was found and concentration decreased over time from $1.6 \mu \mathrm{g} / \mathrm{L}$ after 5 minutes to $1.0 \mu \mathrm{g} / \mathrm{L}$ after 18 hours. Zinc (Zn).-Moderate concentration of zinc was found in the Superior leachate, and zinc concentration increased over time. The 5-minute concentra- tion was $180 \mu \mathrm{g} / \mathrm{L}$, increasing to $387 \mu \mathrm{g} / \mathrm{L}$ after 18 hours.

\section{Wild Irishman Mine}

The Wild Irishman mine is located in the Upper Saints John Creek drainage basin. Saints John Creek flows into the Snake River below the confluence of Deer Creek and the Snake River. Host rock for this mine is Swandyke hornblende gneiss and ore on dump from lower adit indicates veins consisted largely of "manganosiderite" with moderate amounts of galena. On dump above lower adit, manganosiderite is rare and quartz is the dominant gangue mineral. The mine is hosted in the Swandyke hornblende gneiss.

\section{Net-Acidity}

$$
6.5 \mathrm{~kg} \mathrm{CaCO}_{3} / \text { ton. }
$$

\section{pH Trend}

There was a significant increase in $\mathrm{pH}$ over time in the Wild Irishman mine-waste leachate. $\mathrm{pH}$ rose from $\mathrm{pH} 5.5$ after 5 minutes to $\mathrm{pH} 6.6$ after 18 hours. (+1.1 pH units). This indicates net-acid neutralization in the leachate over time.

\section{Specific Conductance Trend}

The leachate had low specific conductance with measurements of $33.5 \mu \mathrm{S} / \mathrm{cm}$ after 5 minutes, rising to $113 \mu \mathrm{S} / \mathrm{cm}$ after 18 hours.

\section{Sulfate}

The sulfate concentration was low with concentrations of $13 \mathrm{mg} / \mathrm{L}$ after 5 minutes and $30 \mathrm{mg} / \mathrm{L}$ after 18 hours.

\section{Selected Major-Element Trends}

Wild Irishman leachate had low calcium concentration that ranged from $2.8 \mathrm{mg} / \mathrm{L}$ in the 5 -minute leach to $12.4 \mathrm{mg} / \mathrm{L}$ after 18 hours.

\section{Selected Trace-Metal Trends}

Following are summaries of selected trace-element trends portrayed in the time study (5-minute vs. 18-hour) of the Wild Irishman mine-waste leachate. Aluminum $(\mathrm{Al})$.- This leachate had aluminum 
concentration that ranged from $20.1 \mu \mathrm{g} / \mathrm{L}$ in the 5 minute leachate and decreased to $2.6 \mu \mathrm{g} / \mathrm{L}$ after 18 hours. There was a net aluminum loss in the leachate over time.

Cadmium $(\mathrm{Cd})$.--Minor concentration of cadmium was found in the leachate with values of $0.16 \mu \mathrm{g} / \mathrm{L}$ after 5 minutes, increasing to $0.43 \mu \mathrm{g} / \mathrm{L}$ after 18 hours.

Copper $(\mathrm{Cu})$.- Minor leachate copper concentration was found and the concentration increased slightly over time. Values ranged from $0.50 \mu \mathrm{g} / \mathrm{L}$ in the 5-minute leachate to $0.55 \mu \mathrm{g} / \mathrm{L}$ after 18 hours. Iron $(\mathrm{Fe})$.- No iron was found in the Wild Irishman leachate at the ICP-MS detection limit. Both the 5-minute and 18-hour leachates were $<50 \mu \mathrm{g} / \mathrm{L}$. Manganese (Mn).--Moderate concentration of manganese was found in the leachate. The 5minute concentration was $281 \mu \mathrm{g} / \mathrm{L}$ and increased to $661 \mu \mathrm{g} / \mathrm{L}$ after 18 hours.

Mercury $(\mathrm{Hg})$.- Mercury was not detected in the Wild Irishman leachate.

Nickel $(\mathrm{Ni})$. - Nickel was found in the leachate with a 5-minute concentration of $0.60 \mu \mathrm{g} / \mathrm{L}$, increasing to $1.0 \mu \mathrm{g} / \mathrm{L}$ after 18 hours.

Lead $(\mathrm{Pb})$.- - Low concentration of lead was found and lead concentration decreased over time from $2.6 \mu \mathrm{g} / \mathrm{L}$ after 5 minutes to $1.3 \mu \mathrm{g} / \mathrm{L}$ after 18 hours. Zinc (Zn).-Moderate concentration of zinc was found in the Wild Irishman leachate, and the zinc concentration increased over time. 5-minute concentration was $6.0 \mu \mathrm{g} / \mathrm{L}$, increasing to $43.8 \mu \mathrm{g} / \mathrm{L}$ after 18 hours.

\section{Grizzly Mine}

The Grizzly mine is located in Grizzly Gulch in the Clear Creek watershed. The mine is hosted in the Idaho Springs formation.

\section{Net-Acidity}

\section{$1.3 \mathrm{~kg} \mathrm{CaCO}_{3} /$ ton.}

\section{$\mathrm{pH}$ Trend}

There was no change in $\mathrm{pH}$ over time in the Grizzly mine-waste leachate. $\mathrm{pH}$ stayed at 6.9 in both the 5-minute and 18-hour leachates. The leachate was neither net-acid producing nor net-acid consuming.

\section{Specific Conductance Trend}

Grizzly leachate had low specific conductance with measurements of $25 \mu \mathrm{S} / \mathrm{cm}$ after 5 minutes, increasing to
$70 \mu \mathrm{S} / \mathrm{cm}$ after 18 hours.

\section{Sulfate}

Sulfate concentration was very low with concentrations of $5 \mathrm{mg} / \mathrm{L}$ after 5 minutes and $8 \mathrm{mg} / \mathrm{L}$ after 18 hours.

\section{Selected Major-Element Trends}

This leachate had low calcium concentration that ranged from $1.8 \mathrm{mg} / \mathrm{L}$ in the 5 -minute leach to $6.9 \mathrm{mg} / \mathrm{L}$ after 18 hours.

\section{Selected Trace-Metal Trends}

Following are summaries of selected trace-element trends portrayed in the time study (5-minute vs. 18-hour) of the Grizzly mine-waste leachate.

Aluminum $(A l)$.- This leachate had moderate aluminum concentration that ranged from $57.1 \mu \mathrm{g} / \mathrm{L}$ in the 5-minute leachate and increased to $364 \mu \mathrm{g} / \mathrm{L}$ after 18 hours.

Cadmium $(\mathrm{Cd})$.-Minor concentration of cadmium was found in the Grizzly mine-waste leachate with values of $<0.02 \mu \mathrm{g} / \mathrm{L}$ after 5 minutes, and $0.03 \mu \mathrm{g} / \mathrm{L}$ after 18 hours.

Copper $(\mathrm{Cu})$.- Minor leachate copper concentration was found. Values ranged from $2.0 \mu \mathrm{g} / \mathrm{L}$ in the 5-minute leachate to $2.2 \mu \mathrm{g} / \mathrm{L}$ after 18 hours.

Iron $(\mathrm{Fe})$.- - Iron was found in low concentration in the leachate, and concentration increased over time from $<50 \mu \mathrm{g} / \mathrm{L}$ in the 5 -minute to $129 \mu \mathrm{g} / \mathrm{L}$ after 18 hours.

Manganese (Mn).-Minor concentration of manganese was found in the Grizzly leachate. The 5minute concentration was $2.7 \mu \mathrm{g} / \mathrm{L}$ and increased to $7.4 \mu \mathrm{g} / \mathrm{L}$ after 18 hours.

Mercury $(\mathrm{Hg})$.- Mercury was not detected in the Grizzly leachate.

Nickel $(\mathrm{Ni})$.- - Nickel was found in low concentration in the leachate with a 5-minute concentration of $<0.4 \mu \mathrm{g} / \mathrm{L}$ that increased to $0.8 \mu \mathrm{g} / \mathrm{L}$ after 18 hours.

Lead $(\mathrm{Pb})$.- - Low concentration of leachate lead was found and concentration increased over time from $4.8 \mu \mathrm{g} / \mathrm{L}$ after 5 minutes to $11.1 \mu \mathrm{g} / \mathrm{L}$ after 18 hours.

Zinc $(\mathrm{Zn})$.--Minor concentration of zinc was found in the Grizzly leachate, and zinc concentrations increased slightly over time. The 5-minute concentration was $5.7 \mu \mathrm{g} / \mathrm{L}$; this value increased to 9.9 $\mu \mathrm{g} / \mathrm{L}$ after 18 hours. 


\section{Waldorf Mine}

The Waldorf mine is located in the very upper reach of Leavenworth Creek in the Clear Creek watershed. The mine is hosted in Idaho Springs schist and rhyolitic intrusive rocks, although Silver Plume granite is present near the adit and is exposed within the tunnel as well. Lovering (1938) reports that the walls of the tunnel were coated with a copper "lime" during his visit

\section{Net-Acidity}

$$
24.0 \mathrm{~kg} \mathrm{CaCO} / \text { ton. }
$$

\section{pH Trend}

An increase in $\mathrm{pH}$ occurred in leachate from the Waldorf mine-waste composite that showed a rise in $\mathrm{pH}$ from 3.1 after 5 minutes to 3.3 after 18 hours. (+0.2 pH units). This indicates some neutralization of the leachate over time.

\section{Specific Conductance Trend}

Leachate from the Waldorf mine-waste had high specific conductance with measurements of $1,040 \mu \mathrm{S} / \mathrm{cm}$ after 5 minutes, rising to $1,092 \mu \mathrm{S} / \mathrm{cm}$ after 18 hours.

\section{Sulfate}

Waldorf leachate sulfate concentration increased over time from $443 \mathrm{mg} / \mathrm{L}$ after 5 minutes to $504 \mathrm{mg} / \mathrm{L}$ after 18 hours.

\section{Selected Major-Element Trends}

Waldorf leachate had the second highest leachate concentration of calcium that ranged from $82 \mathrm{mg} / \mathrm{L}$ in the 5-minute leachate to $120 \mathrm{mg} / \mathrm{L}$ after 18 hours.

\section{Selected Trace-Metal Trends}

Following are summaries of selected trace-element trends portrayed in the time study (5-minute vs. 18-hour) of the Waldorf mine-waste leachate.

Aluminum ( $A l)$.-Waldorf leachate had the highest aluminum concentration of the 13 dumps included in this study. Aluminum concentration decreased slightly over time. Concentration was $8,230 \mu \mathrm{g} / \mathrm{L}$ in the 5-minute leachate and decreased to $8,010 \mu \mathrm{g} / \mathrm{L}$ after 18 hours.
Cadmium $(\mathrm{Cd})$.--Elevated concentrations of cadmium were found with concentrations of $122 \mu \mathrm{g} / \mathrm{L}$ after 5 minutes, rising to $140 \mu \mathrm{g} / \mathrm{L}$ after 18 hours. Copper $(\mathrm{Cu})$.-Waldorf leachate copper concentration was second highest of all the leachates studied. Only leachate from the Santiago mine-waste had higher copper concentrations. Waldorf leachate copper ranged from 4,400 in the 5-minute leachate to $4,410 \mu \mathrm{g} / \mathrm{L}$ after 18 hours.

Iron $(\mathrm{Fe})$.-Waldorf leachate iron concentration was high, especially in the 5-minute leachate. A decrease in iron concentration was seen over time from $7,910 \mu \mathrm{g} / \mathrm{L}$ in the 5 -minute leachate to 744 $\mu \mathrm{g} / \mathrm{L}$ after 18 hours. This is a decrease in iron concentration of more than an order of magnitude. Manganese (Mn).-Very high concentration of manganese was found in leachate from the Waldorf mine-waste, second only to the Santiago. The 5minute concentration was $31,500 \mu \mathrm{g} / \mathrm{L}$; this value increased to 40,900 after 18 hours.

Mercury $(\mathrm{Hg})$.- - Mercury was not detected in the Waldorf leachate.

Nickel (Ni).-Elevated concentrations of nickel were found in the leachate with a slight increase in leachate concentration over time. The 5-minute concentration was $117 \mu \mathrm{g} / \mathrm{L}$; this value increased to $126 \mu \mathrm{g} / \mathrm{L}$ after 18 hours.

Lead $(\mathrm{Pb})$.- - Leachate lead concentration increased over time from $190 \mu \mathrm{g} / \mathrm{L}$ after 5 minutes to 1,290 $\mu \mathrm{g} / \mathrm{L}$ after 18 hours.

Zinc ( $\mathrm{Zn})$.- - Very high concentrations of zinc were found in the Waldorf leachate and zinc concentrations increased over time. The 5-minute concentration was $23,900 \mu \mathrm{g} / \mathrm{L}$, increasing to 25,500 after 18 hours.

\section{Santiago Mine}

The Santiago mine is located near the Waldorf mine in the Leavenworth Creek/Clear Creek watershed. Host rock is Silver Plume granite and biotite-quartz-sillimanite schist. One of the largest producers in the area the ore consisted of galena, sphalerite, pyrite and some chalcopyrite; quartz and ankerite comprise the dominant gangue minerals and ankerite was reported to be very abundant in some of the deeper workings.

\section{Net-Acidity}

$73.0 \mathrm{~kg} \mathrm{CaCO} /$ ton.

\section{pH Trend}

An increase in $\mathrm{pH}$ occurred in leachate from the Santiago mine-waste composite that showed a spike in $\mathrm{pH}$ from 3.6 
after 5 minutes to 5.2 after 18 hours ( $+1.6 \mathrm{pH}$ units). This indicates neutralization of the leachate over time.

\section{Specific Conductance Trend}

Leachate from the Santiago mine-waste had the highest specific conductance of all the 13 dumps studied, with specific conductance of $1,730 \mu \mathrm{S} / \mathrm{cm}$ after 18 hours. This followed the 5 -minute reading of $1,396 \mu \mathrm{S} / \mathrm{cm}$.

\section{Sulfate}

Santiago leachate had the highest concentration of sulfate, and the concentration increased over time from $736 \mathrm{mg} / \mathrm{L}$ after 5 minutes to $1,040 \mathrm{mg} / \mathrm{L}$ after 18 hours.

\section{Selected Major-Element Trends}

Santiago leachate had the highest concentration of calcium, ranging from $230 \mathrm{mg} / \mathrm{L}$ in the 5 -minute leachate to 370 $\mathrm{mg} / \mathrm{L}$ after 18 hours. The high calcium concentration is probably responsible for the increase in the leachate $\mathrm{pH}$ over time.

\section{Selected Trace-Metal Trends}

Following are summaries of selected trace-element trends portrayed in the time study (5-minute vs. 18-hour) of the Santiago mine-waste leachate.

Aluminum $(\mathrm{Al})$. - Found to be high in the 5-minute leachate at 2,060 $\mu \mathrm{g} / \mathrm{L}$ but decreased after 18 hours to a concentration of $11.3 \mu \mathrm{g} / \mathrm{L}$.

Cadmium $(C d)$.- Slightly elevated concentrations of cadmium were found with concentrations of 174 $\mu \mathrm{g} / \mathrm{L}$ after 5 minutes, and $180 \mu \mathrm{g} / \mathrm{L}$ after 18 hours. Copper $(\mathrm{Cu})$.-Copper concentration was high in the 5-minute leachate at $6,590 \mu \mathrm{g} / \mathrm{L}$ but decreased to $236 \mu \mathrm{g} / \mathrm{L}$ after 18 hours.

Iron $(\mathrm{Fe})$. - Leachate iron was elevated in the 5minute leachate at $836 \mu \mathrm{g} / \mathrm{L}$ and decreased to $<50$ $\mu \mathrm{g} / \mathrm{L}$ after 18 hours.

Manganese (Mn).--Very high concentration of manganese was found in leachate from the Santiago. The 5-minute concentration was 44,200 $\mu \mathrm{g} / \mathrm{L}$ increasing to 56,100 after 18 hours.

$\operatorname{Mercury}(\mathrm{Hg})$.- Mercury was detected in the leachate from the Santiago mine-waste pile. Mercury concentration was $25 \mathrm{ng} / \mathrm{L}$ (ppt) after 5 minutes, rising to $30 \mathrm{ng} / \mathrm{L}$ (ppt) after 18 hours.

Nickel (Ni). - Slightly elevated in the leachate with a slight increase in leachate concentration over time. 5 -minute concentration was $120 \mu \mathrm{g} / \mathrm{L}$; this value increased to $133 \mu \mathrm{g} / \mathrm{L}$ after 18 hours.
Lead $(P b)$.—Leachate lead decreased from $234 \mu \mathrm{g} /$ $\mathrm{L}$ after 5 minutes to a concentration of $28.1 \mu \mathrm{g} / \mathrm{L}$ after 18 hours.

Zinc (Zn).--Very high concentration of zinc was found in the leachate and zinc concentration decreased over time. The 5-minute concentration was $26,000 \mu \mathrm{g} / \mathrm{Lthe} 18$-hour value dropped to $22,600 \mu \mathrm{g} / \mathrm{L}$. 